IFN Working Paper No. 782, 2009

Childcare Costs and the Demand for Children Evidence from a Nationwide Reform

Eva Mörk, Anna Sjögren and Helena Svaleryd 


\title{
Childcare costs and the demand for children - Evidence from a nationwide reform *
}

\author{
By \\ Eva Mörk $^{\mathrm{a}}$, Anna Sjögren ${ }^{\mathrm{b}}$ and Helena Svaleryd ${ }^{\mathrm{c}}$ \\ August 2011
}

\begin{abstract}
Exploiting the exogenous variation in user fees caused by a Swedish childcare reform, we are able to identify the causal effect of childcare costs on fertility in a context in which childcare enrollment is almost universal, user fees are low, and labor force participation of mothers is very high. Anticipation of a reduction in childcare costs increased the number of first and higher order births, but only seemed to affect the timing of second births. For families with many children we also find a marginally significant negative income effect on fertility.
\end{abstract}

Keywords: Childcare, Cost of children, Fertility, Quasi-experiment, Difference-in-differences JEL-codes: H31, J13

\footnotetext{
* We are grateful for comments by two anonymous referees as well as from Matz Dahlberg, Peter Fredriksson, Christian Holzner, Rafael Lalive, Imran Rasul and participants at seminars at IFN, IFAU, SOFI, Stockholm University, Växjö University, the IFN Stockholm Conference on Family, Children and Work and the 23rd Annual Congress of EEA in Milan, SOLE 2009, the ELE Summer Institute, Bergen 2009, the Econometric Society's 2009 North American Summer Meeting in Boston, the 2009 NBER Summer Institute, the 2009 IIPF Congress in Cape Town and the 2010 ASSA Meeting in Atlanta.

a Department of Economics, Uppsala University, PO Box 513, SE-751 20 Uppsala, Sweden; CESifo, IEB, IFAU, IZA, UCFS and UCLS.

${ }^{\mathrm{b}}$ IFAU, PO Box 513, SE-751 20 Uppsala, Sweden; IFN and SOFI.

${ }^{\mathrm{c}}$ IFN, Box 55665, SE-102 15 Stockholm, Sweden.
} 


\section{Introduction}

Low fertility rates, aging populations, and the concern for long-term labor supply have inspired policy interest in how the availability and price of childcare services influence maternal labor supply and birth rates. Cross-country comparisons show that birth rates are indeed higher in OECD countries with high female labor force participation and wide access to childcare (D'Addio and Mira d'Ercole, 2005). However, the direction of causality is not well understood.

In this paper we aim to establish if, and how, childcare costs affect fertility. To this end, we use the quasi-experiment initiated by a Swedish childcare reform that standardized the fee schedules across Swedish municipalities and imposed a cap on childcare charges. Consequently, households with similar characteristics experienced different cost changes depending on where they lived, and households in a given municipality experienced different cost changes depending on characteristics such as household income and the number and age of the children. Hence, conditional on household characteristics, the reform introduced exogenous variation in childcare costs.

Theoretical models of fertility and maternal labor supply (e.g., Ermisch, 1989a, b; Apps and Rees, 2004) predict that reductions in childcare costs may affect both fertility and the labor supply of mothers. By increasing mothers' take-home wages, lower childcare costs make it more attractive to enter the labor market or to work longer hours. However, for working mothers, lower childcare costs imply a direct reduction in the cost of having children, which in turn should increase the demand for children. Hence, the effects of childcare costs on fertility are likely to depend on women's labor supply decisions. A recent study by Lundin et al. (2008) of the same reform that we investigate, using similar estimation techniques, finds no effects on maternal labor supply, suggesting that fertility may be the margin of adjustment. ${ }^{1}$

Previous micro studies have found mixed support for the hypothesis that lower childcare charges increase fertility. Using American survey data, Blau and Robins (1989) conclude that higher childcare costs decrease the birth rates of unemployed women but have no effect on

\footnotetext{
${ }^{1}$ Note that even though maternal labor force participation is high in Sweden, many mothers with small children work parttime, so that there was the potential for an increased labor supply.
} 
employed women. In a study of Italian data, Del Boca (2002) finds that both fertility and labor force participation are positively correlated with better access to childcare. These studies, however, suffer from endogeneity problems. Both the availability of childcare and the charges actually paid by families vary according to local governments' responses to demand or to families' individual choices about the quality and quantity of care.

In a more recent study, Schlosser (2006) examines the introduction of free public preschool for children aged 3 and 4 in Israel to estimate the effects of a reduction in childcare costs on Arab mothers' labor supply and fertility. She finds no effect on fertility but a positive effect on labor supply. Schlosser uses quasi-experimental data and is therefore more likely to capture causal effects rather than correlations. Given the context studied by Schlosser; a case where fertility was initially high, while maternal labor supply was very low, the results are perhaps not so surprising.

Two recent studies on US data examine the effects on labor supply and fertility using changes in household service sector wages caused by low-wage immigration. Cortes and Tessada (2009) find positive effects on the female labor supply, and especially on highly educated mothers who worked longer hours. Furtado and Hock (2010) show that lower wages in the childcare sector resulted in higher fertility for highly educated women. ${ }^{2}$

The US context is in many ways similar to that studied here: most Swedish women work, have children and use childcare. However, important differences exist, in particular regarding which groups were affected by the studied price changes. While low-skill immigration primarily lowered the price of flexible nanny services, making it easier for high-earning women to combine career and family, the present study examines changes in the already low cost of publicly subsidized childcare during regular work hours. Another important difference is that the type of childcare studied in this paper is used by the vast majority of Swedish families. In 2004, the attendance rate for children aged 3-6 was 90 percent. Hence, as opposed to the American price reduction studied by Cortes and Tessada and Furtado and Hock, the Swedish price reduction is not targeted to any specific group of parents and was enjoyed by practically all Swedish families. However, given that publicly subsidized childcare is only available during regular working hours, there was limited possibility for families to demand more hours for childcare other than by enrolling more children.

\footnotetext{
${ }^{2}$ In a related field, a number of studies investigate the impact of other financial incentives, such as child allowances and tax incentives, on fertility decisions (see e.g., Cohen et al, 2009, Kearney, 2004, Laroque and Salanié, 2004 and Milligan, 2005).
} 
An important advantage of the present study is that we can estimate the effect of cost changes on wide range of households drawn from different parts of the income distribution as opposed to reviewing only on a small segment of the population, which is a common weakness of studies using quasi-experiments. This strengthens the external validity of our results (see discussion in Moffitt, 2005; and Angrist et al, 2010), in particular regarding families with at least one previous child where the analysis covers the vast majority. The analysis of first births is however, restricted to married couples which limits our ability to generalize the conclusions.

We find limited effects of the price changes on the fertility behavior of Swedish families. The reduction in childcare costs which in total corresponded to a quarter of one-year household earnings for childless couples, had a positive effect on first births which increased by 9.5 percent. This corresponds to an increase of 5.5 percent for a 10,000 US dollar reduction in the present value of the future marginal child care costs. For families with children, on the other hand, we only find statistically weak evidence on the timing for higher order births. On average, families were induced to have an additional child slightly earlier than planned, but there was no effect on total fertility. A closer look at different parities suggests families with one child seem to have reacted immediately by postponing the second child when the election promise to cap childcare fees was announced, perhaps to make sure the reform was actually launched before they went ahead and had their second child. There was however no significant overall effect on second births. For families with two or more children, we find a statistically weak positive fertility response to the reduction in childcare costs. In addition to marginal cost changes, families with children also benefitted from reductions in the child care costs for the children they already had. There is weak evidence that families with two or more children reduced their fertility in response to this income transfer suggesting a negative income effect. We find evidence of stronger effects for low income households. Furthermore for first births the positive fertility effects of the reform is stronger in municipalities with a high share of votes for the Social Democrats, the political party that first announced the childcare reform as an election promise and then implemented the reform once in office.

Before we present the data, discuss our identification strategy in some detail, and arrive at estimation results, we provide background information on Swedish childcare institutions and 
the design of the childcare reform of 2002. We also describe recent developments regarding birth rates for Swedish women.

\section{Institutional background}

\subsection{Childcare in Sweden}

Sweden has a long tradition of publicly subsidized childcare for pre-school children and afterschool care for young school-age children. Figure 1 shows the fraction of children attending some form of publicly subsidized childcare over time, by age. Enrollment rates have increased dramatically, and in 2004, 90 percent of all children in the 3-6 age group attended childcare. ${ }^{3}$ The enrollment rate is also high for very young children (aged 1-2). One explanation for these high enrollment rates is that local governments in Sweden are obliged by law to provide highly subsidized, high-quality childcare for children aged 1-12 whose parents either work or are full-time students; care is to be arranged within three to four months of the parents' request. ${ }^{4}$ Subsidized childcare for infants is, however, restricted to families and children with special needs, and hence, enrollment for infants is negligible. ${ }^{5}$

\footnotetext{
${ }^{3}$ Publicly subsidized childcare comes in different forms, the most common being center-based care. Different forms of family daycare - e.g., care provided in a publicly-paid caretaker's home or in the child's home-also exist, although to a rather small extent (in 2001, only 5 percent of all enrolled children had this type of care). Although the financing of childcare is public, care providers can be public, cooperative or private. Until the early 1990s, childcare was almost exclusively publicly provided; since then, a growing proportion of municipalities have introduced voucher systems, paving the way for the private provision of services. These private child care centers still have to follow the nationally set curriculum.

4 There are 290 local governments in Sweden. In addition to arranging childcare, they are responsible for primary and secondary education, care of the elderly and disabled, welfare and local infrastructure. Local governments finance their activities through (in order of their importance) proportional local income tax, grants from the central government, and user fees.

${ }^{5}$ Infants are instead cared for by their parents. Parents are entitled to a year's paid parental leave with an income replacement rate of 80 per cent up to a cap.
} 
Figure 1 The proportion of children enrolled in subsidized childcare by age, 1976-2004

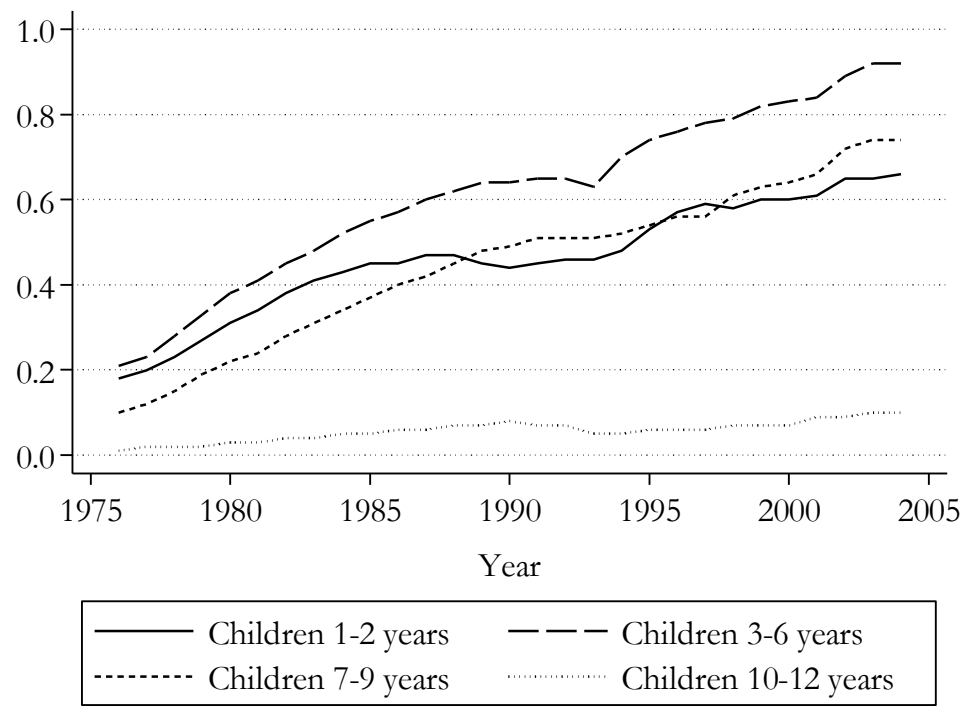

Source: National Board of Education (Skolverket)

Daycare centers offer services during regular work hours. Enrolled children spend on average 32 hours per week at daycare. Although mothers who work full-time have their children in daycare for longer hours than mothers working half-time (34 vs. 21 hours per week in 2005), very few children, even those with both parents working full-time, attend daycare more than 40 hours per week. ${ }^{6}$ Anecdotal evidence also suggests that strong social norms regulate what parents view as adequate staying time. It is therefore interesting to note that attendance times did not change during the period of study (Skolverket, 2007), although childcare became cheaper.

Until 2002, the municipalities were free to set their own childcare charges as long as these were "reasonable". According to Government Bill 93/94:11, "child care charges must not be so high that parents, for economic reasons, refrain from letting their child attend a childcare activity that the child would benefit from". This definition clearly left room for different interpretations, and consequently, childcare fee schedules differed considerably between municipalities with respect to both levels and construction. In particular, charges varied with family income and the age and number of the children. Some municipalities applied a flat charge per child, but most municipalities used complicated fee schedules such that families with high incomes and few children paid the highest charges per child. However, childcare

\footnotetext{
${ }^{6}$ The father's work time has a much smaller impact on attendance time. Men are also much less likely to work part-time (Skolverket, 2007).
} 
was heavily subsidized in all municipalities, and only about 15-20 percent of the municipalities' childcare costs were covered by user charges.

Quality of daycare, both before and after the reform, has remained relatively homogenous both within and across municipalities. According to Table 1, which displays municipal averages for some indicators of childcare quality, the total expenditure per child and personnel intensity has not changed dramatically over time. If anything, municipalities spend more per enrolled child after the reform than before. Also there is no reason to expect that wealthier families will have access to higher-quality daycare either within a particular municipality or between municipalities. For example, the correlation between the average child/teacher ratio and the average income across municipalities in 1999 was virtually zero. A reason for this absence of relationship is that childcare subsidies are financed through the municipal budget along with several other municipal responsibilities such as care for the elderly, education and social welfare. ${ }^{7}$ Moreover, user fees are strictly regulated, and hence, childcare services can only be adapted to meet parental preferences for quality within a given budget. There is therefore no connection between fees paid by a particular parent and the quality of the daycare center that the child attends.

Table 1 Municipal level indicators of childcare quality

\begin{tabular}{|c|c|c|c|c|c|c|}
\hline & 1999 & 2000 & 2001 & 2002 & 2003 & 2004 \\
\hline $\begin{array}{l}\text { Municipal annual } \\
\text { expenditure per } \\
\text { enrolled child, SEK } \\
\text { (2001 prices) }\end{array}$ & 85,900 & 89,000 & 90,200 & 91,700 & 92,100 & 92,400 \\
\hline $\begin{array}{l}\text { Number of enrolled } \\
\text { children per worker }\end{array}$ & 5.3 & 5.4 & 5.3 & 5.3 & 5.4 & 5.4 \\
\hline $\begin{array}{l}\text { Share of personnel } \\
\text { with training in } \\
\text { pedagogics }\end{array}$ & $54 \%$ & $54 \%$ & $52 \%$ & $51 \%$ & $51 \%$ & $51 \%$ \\
\hline
\end{tabular}

Source: http://www.skolverket.se/sb/d/1663 (The Swedish National Agency for Education)

\footnotetext{
${ }^{7}$ Also differences in income due to differences in the tax base are in principal equalized across municipalities.
} 


\subsection{The childcare reform}

In the last months of the election campaign before the 1998 elections, the incumbent (The Social Democrats) party proposed a large childcare reform designed to reduce user fees and further increase the accessibility of childcare. ${ }^{8}$ The Social Democrats won the election, and the reform bill was passed by parliament in November 2000. The motivation for the reform was i) to give all children equal access to early education ii) to improve economic conditions for families with young children, and iii) to promote parental labor force participation.

The reform was implemented gradually and consisted of several parts. The most important component, and the one studied here, was an option for municipalities to, beginning in January 2002, impose a cap (set by the central government) on user fees for childcare. ${ }^{9}$ Municipalities that chose to do so were granted compensation (at least partially) for lost revenues. As it turned out, all but two municipalities decided to implement the capped fee schedule already in January 2002. The decisions were in most cases made in the fall of 2001. The remaining two municipalities implemented the reform in the following year. ${ }^{10}$

The capped fee schedule, which has been in place since the reform, has two components. First, the charge per child is determined as a fixed percentage of household income. The rate varies with the age and birth order of the children, such that care for younger children and children with few siblings in childcare costs more. ${ }^{11}$ Secondly, per-child fees are capped and are thus constant beyond a monthly income ceiling, which was SEK 38,000 (6,430 USD) in 2002. The maximum amount paid by any household was SEK 2,280 (385 USD) per household and per month in 2002.

Prior to the reform, there was substantial variation in childcare fees across household types and municipalities. Since the reform, comparable households have faced similar childcare charges regardless of where they live. Overall, childcare became cheaper as a result of the reform. In 1999, the median middle-income family with two adults and two children in preschool paid SEK 2,660 (380 USD) per month, and childcare charges ranged from SEK 1,560

\footnotetext{
${ }^{8}$ Elinder, et al. (2008) analyze the reform's impact on voter behavior and find that families with young children increased their propensity to vote for the incumbent government.

${ }^{9}$ The reform also introduced a right for children whose parents were unemployed or on parental leave to attend childcare for a minimum of 15 hours per week.

${ }^{10}$ These municipalities are not included in the study.

${ }^{11}$ The percentage rate for the first child in preschool is 3 percent; the rate is 2 percent for the second child and 1 percent for the third child. The corresponding figures for after-school care are 2, 1 and 1 percent. The household does not pay anything for child number four or for any children thereafter. The youngest child is defined as child number 1 . Hence, families with one child in preschool and one in after-school care pay 4 percent of household income.
} 
(260 USD) to SEK 3,940 (670 USD) depending on where the family lived (Skolverket, 1999). In 2002, after the implementation of the reform, a similar family paid SEK 1,900 (320 USD) on average for the care of their two children, and charges ranged between SEK 1,040 (175 USD) and SEK 1,900 (320 USD) (Skolverket, 2003). Hence, there was also some variation after the reform because municipalities were allowed to charge lower fees than indicated in the national schedule, a possibility that a tiny minority of the municipalities used.

\subsection{Fertility and maternal labor supply in Sweden}

From a European perspective, the labor force participation of Swedish women is high; it is about 88 percent of the male participation rate. Women are, however, more likely to work part-time than men. Part-time work is especially prominent among women with small children. One reason is that parents with small children have a legal right to work shorter hours (75 percent of full-time). As is shown in Figure 2, about 80 percent all of women with small children are employed, and half of them work part-time. A closer examination of the work hours of women with small children shows that there are peaks at 100 and 75 percent, respectively (OECD, 2005). Figure 2 shows a slight upward trend in full time employment since the 1980's but that overall employment is rather stable. The trends are broken in the early 1990's and to a lesser extent also at a time contemporary with the reform studied in this paper. Both periods of decline coincide with periods of increased unemployment in the economy as a whole. One may hence be concerned that the reform studied in this paper was introduced in response to declines in female employment or that the reform itself had an impact on female employment, as was its aim. However, Lundin et al (2008) find no employment response to the change in childcare prices caused by the reform.

In contrast to most OECD countries, where completed fertility rates have fallen considerable over the past few decades, completed fertility in Sweden has remained rather stable (see Björklund, 2006). The cohorts of women born 1926-59 had completed fertility rates around 2.0, with the highest rate (2.11) for the cohort born in 1943 and lowest rate (1.96) for the cohort born in 1945. 
Figure 2 Fraction of women employed and working full-time for different ages of youngest child.

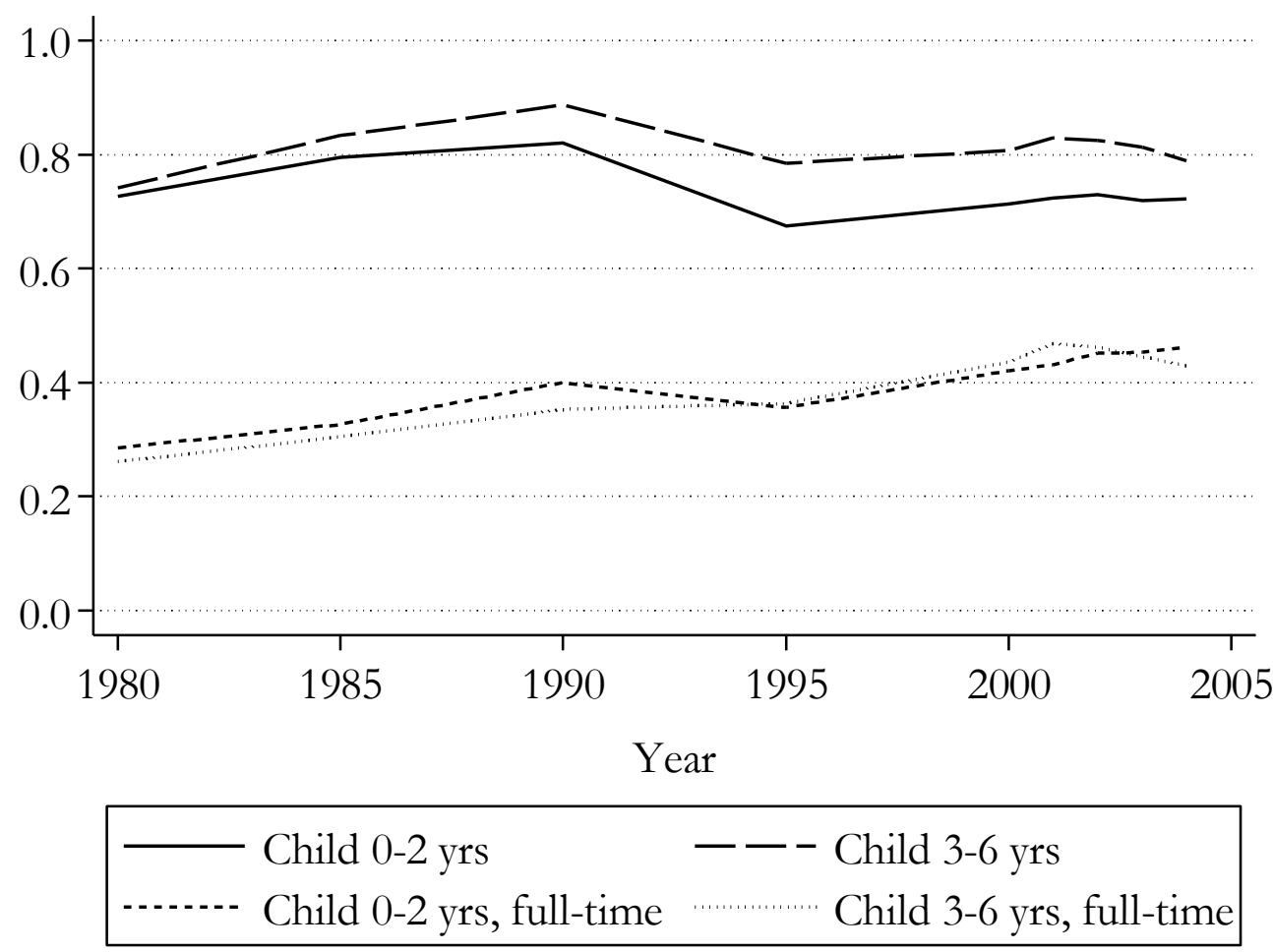

Source: OECD (2005)

Total fertility rates ${ }^{12}$ of Swedish women, however, fluctuate substantially over time. Figure 3 shows the average number of children born per woman aged 20-45 in Sweden over the period 1968-2006. The figure demonstrates a recession in the late 1970s and early 1980s, followed by a boom in the late 1980s and early 1990s and lower levels again in the late 1990s. Total fertility rates have, however, picked up in recent years from an all-time low of 1.5 in 1999.

\footnotetext{
${ }^{12}$ Total fertility in a given year shows how many children a hypothetical woman would have in her lifetime if she had as many children at each age as women of a given age in that particular year.
} 
Figure 3 The average number of children born per woman aged 20-45 in Sweden during the period 1968-2006.

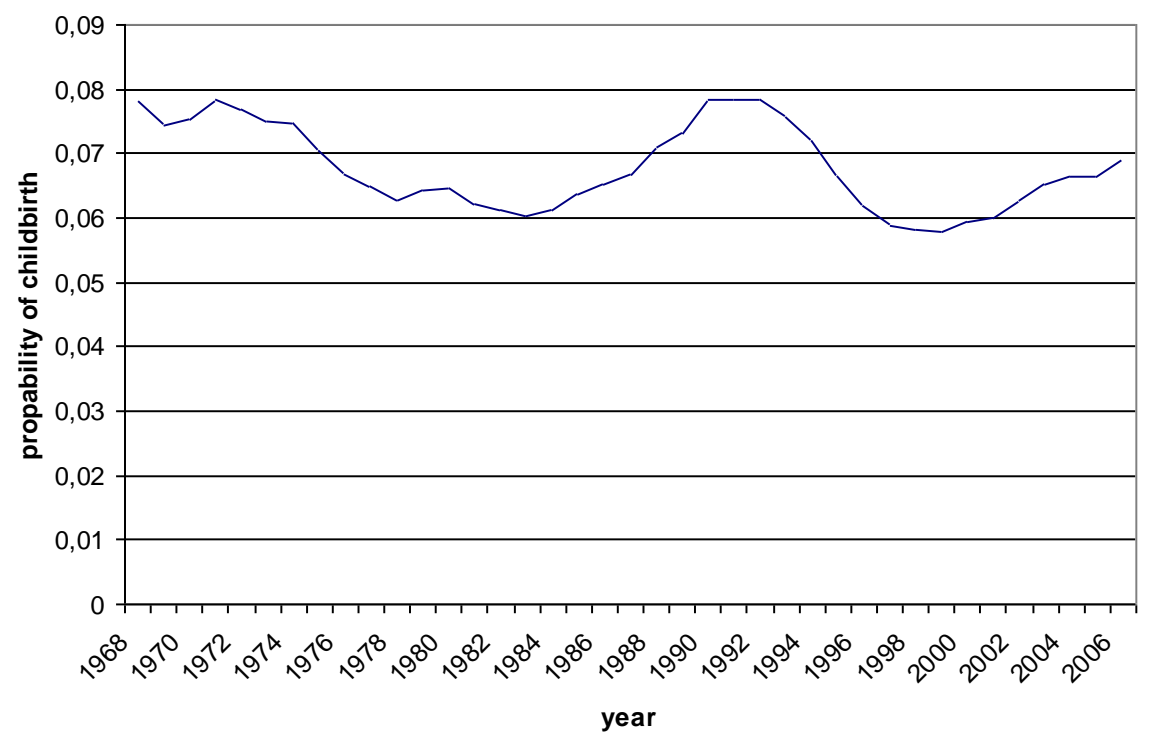

Source: Statistics Sweden

The fluctuations in total fertility largely mirror the development of the labor market with a lag of a few years, suggesting a link between the two. The correlation between total fertility and labor market opportunities is likely to depend on the design of the Swedish parental benefit system, which requires parents to qualify for income-related benefits by working prior to pregnancy and birth. The qualifying rules provide a strong incentive for women to postpone having children until they are established in the labor market (Björklund, 2006). ${ }^{13}$

Interestingly, these aggregate numbers show a slight increase in the number of children born after the Swedish childcare reform. Taking a closer look at the (seasonally adjusted) monthly number of births for the years around the reform, we see that the raw numbers do suggest that the increase in the birth rate is rather well timed in relation to the reform. Figure 4 shows the monthly number of births in excess of the monthly average for the 1995-2004 time period by month from January 1998 through December 2004. The figure suggests that there is a take-off in births in spring of 2002. However, given the magnitude of the long-run cyclical fluctuations in fertility, we cannot readily interpret this increase as a causal effect of

\footnotetext{
${ }^{13}$ See Adsera $(2004,2005)$ for discussions of the link between unemployment and fertility in explaining crosscountry differences in fertility.
} 
decreased childcare costs due to the reform. In order to establish a causal link, we need to show that the changes in fertility behavior across different types of households are, in fact, related to how these household types were affected by the reform. In the next section, we discuss the empirical methodology in detail and present the data used to investigate this link.

Figure 4 Seasonally adjusted monthly birth rate 1998-2004.

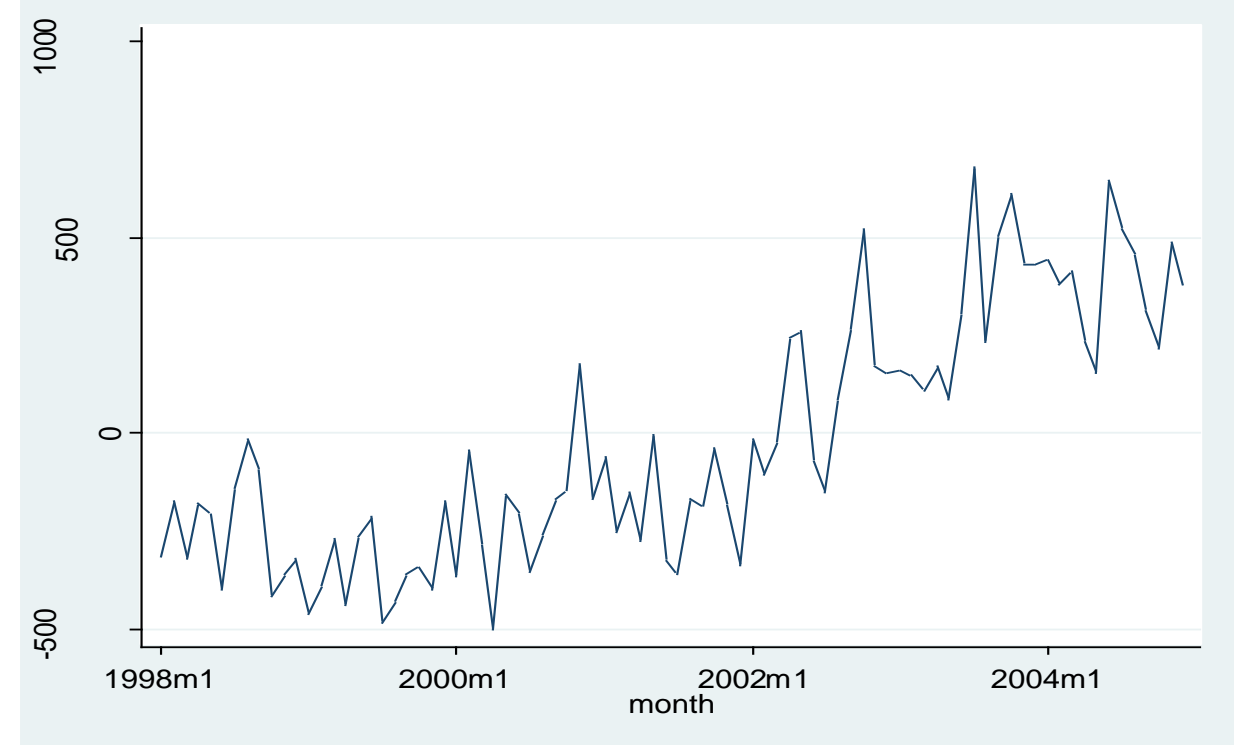

Source: Statistics Sweden.

The figure displayed for month $i$ year $j$ is $\left(\right.$ births $_{\mathrm{ij}}{ }^{-}$mean $\left(\right.$births $\left._{\mathrm{i} 1995-2004}\right)$ ).

\section{Methodology and data}

\subsection{Econometric challenge}

\subsubsection{Empirical strategy}

The problem that arises when one aims at estimating the effect of childcare costs on fertility is that observed childcare costs for a given household are typically determined by household characteristics that are also likely to directly influence fertility decisions. If the Swedish childcare reform had implied that changes in childcare charges were truly random and thereby independent of household characteristics, it would be straightforward to estimate the effect of the cost changes on fertility. However, this was not the case. The fees were reduced more for some types of households than others. In order to achieve unbiased estimates indicating the causal effect of childcare costs on fertility, we therefore need to hold constant all household 
characteristics that determine both childcare charges and fertility decisions. In many applications, this means controlling for unobserved characteristics. However, a survey of childcare fees conducted by IFAU (for details, see Section 3.3) shows that fee schedules, both before and after the reform, are fully determined by a subset of observable household characteristics, which makes estimating causal effects possible.

We denote the subset of household characteristics ${ }^{14}$ that determines childcare fees by $\mathrm{Z}$ and define $\mathbf{J}$ household types as households sharing the same characteristics $Z_{j}$ where $\mathrm{j} \in\{1, \mathrm{~J}\}$, such that in a given municipality $m$ in a given time period, $t$, all households of type $j$ have identical childcare costs. In other words, for households of type $j$, the household's childcare costs are a function $P_{m t}\left(Z_{j}\right)$. It follows that any variation in childcare costs within household type $j$ in a given municipality is a result of changes in the fee schedule $P$ over time. All possible direct effects of $Z_{j}$ on fertility can be accounted for by including a fixed effect for each municipality-household type $Z_{j m}$. More formally, we estimate the following relationship:

$$
\text { Child }_{i j m t}=\alpha+\beta P_{m t}\left(Z_{j}\right)+Z_{j m}+\tau_{t}+\varepsilon_{i j m t}
$$

where Child $_{i j m t}$ is the probability that the woman in household $i$ of type $j$, in municipality $m$ and in time period $t$, bears a child, and where $\tau_{t}$ is a time-fixed effect controlling for a common time variation in fertility. Including controls for household characteristics that influence fertility but do not influence childcare costs (e.g., maternal age and education) is not necessary for unbiased estimates of $\beta$, conditional on an assumption of homogenous responses to the price change. Including such controls may, however, increase efficiency, which is why we will do so in the analysis. See discussion in Smith and Todd (2005). As discussed in section 2.3 unemployment may reduce fertility since employment is required to qualify for the parental benefit system. We therefore control for the local unemployment rate.

Our estimation strategy is to compare the probability that the women in households of a particular type, in a particular municipality, bear children during a time window of a given length prior to the reform to the probability that women in households of that same type in the

\footnotetext{
${ }^{14}$ The variables that determine childcare charges are household income, the number of children and the age of each child. These are all available in Swedish register data, and it is therefore possible to compute each household's exact childcare fee both before and after the reform, on the assumption that all children of childcareeligible age are enrolled in full-time childcare. We return to this issue in Section 3.4.
} 
same municipality have children in a time window of the same length after the reform. ${ }^{15}$ The changes in fertility behavior are then related to the changes in childcare costs induced by the reform for the same household type across different municipalities and for other types of households in the same municipality. This strategy produces a difference-in-differences estimator, where households are matched and compared at the household typexmunicipality level. The resulting estimate of $\beta$, is the weighted-sum over all household types of the difference-in-differences estimates of fertility changes across municipalities and time within a given household type, where the weights are determined by the number of households grouped together for each household type $j$.

\subsubsection{Potential challenges to identification}

The identifying assumption behind equation (1) is that controlling for fixed time-effects and household typexmunicipality effect is enough to capture everything that varies at the household type level or at the municipality level and also correlates with the reform induced changes in childcare costs. One thing that the specification in equation (1) does not allow for is trends at the household type level or at the municipality level. If households with certain characteristics or households in some municipalities exhibit specific trends that are unrelated to the reform but co-varies with the price changes, $\beta$ can no longer be interpreted as a causal effect. This type of pattern may be due to underlying trends, unobserved changes in general policy or local reforms. Our strategy to avoid misinterpreting correlations as causations is to conduct placebo-experiments, where we estimate effects of the childcare reform already before the reform was announced. If we then find a statistically significant effect of the future reform, we will conclude that the model is not correctly specified and re-estimate the model allowing for different sets of trends and time-specific effects before interpreting the point estimates as causal effects.

Another issue of concern is whether the childcare reform had effects on the quality of the care provided and/or whether access to care was affected as a result of increased demand. Such effects could, potentially, confound the effects on fertility of a reduction in fees. As regards the provision of care services, the reform is not likely to have had any major impact on access to childcare because municipalities had been obliged by law to provide a child with

\footnotetext{
${ }^{15}$ The reason that we compare household of the same type over time rather than to follow the same households over time is that the children in the households will be older after the reform than before and we believe that age of already born children is very likely to have a direct effect on the fertility behavior of mothers.
} 
childcare within 3 months of parental demand as early as 1993. This obligation did not change. The reform, however, implied guaranteed access to childcare for a minimum of 15 hours per week for the children of unemployed persons and parents on parental leave caring for new siblings of their older children. These are the reasons for the increase in enrollment seen in Figure 1 above. However, as discussed earlier and shown in Table 1, the number of enrolled children per childcare employee, as well as the share of childcare employees with training in pedagogics, remained constant between 2001 and 2003. Furthermore, if anything, the total cost per enrolled child increased slightly between 2001 and 2003 . Hence, there is no evidence that the reform implied lower-quality childcare.

Our identification strategy assumes that the reform induced cost changes for each household-municipality type are exogenous and do not depend on other characteristics affecting fertility decisions and fees. It is therefore problematic if families that were insensitive to the cost of childcare were more likely to reside in municipalities with high fees prior to the reform. In this case, the households receiving the largest reductions would be the least responsive to changes in childcare costs. Such a selection problem might lead us to underestimate the impact of the reform on fertility and may potentially bias our results against finding any effects. However, it is also possible that fees were high in some municipalities, prior to the reform, in response to an inflow of families demanding childcare for their children. It is not clear how such families bias the results. Another possibility is that the reform encouraged families planning more children to move to locations where they would receive large fee cuts. The method of reducing the biases resulting from families' residence decisions due to the reform that we adopt in the analysis is to compute household childcare fees and register fertility in the municipality of residence prior to the reform. This implies that, if families move in response to the fee cuts we will register childbirths in the wrong municipality and, as a result, underestimate the magnitude of the effects. To make sure that our results are not driven by the, possibly endogenous, moving patterns of individuals, we also perform a robustness check where we exclude households that have recently moved into the municipality as well as households that move away from the municipality. 


\subsection{When do people react to the reform?}

Several years passed between the Social Democrats' first launching of the idea of a childcare fee reform in 1998 and the actual implementation of the capped fees in 2002. Table 2 below presents different important dates for the reform.

Table 2 Timing of the reform

\begin{tabular}{l|ll}
\hline Year & Event & $\begin{array}{l}\text { First births } \\
\text { potentially } \\
\text { affected }\end{array}$ \\
\hline 1998 & Election promise and election victory of the Social Democrats & July 1999 \\
1999 & The fee reform bill is prepared in the government & July 2000 \\
2000 & Decision made at the central level & July 2001 \\
2001 & Decisions made at the local level & July 2002 \\
2002 & The capped fees implemented & July 2003 \\
\hline
\end{tabular}

It is far from obvious when we should expect household to react to the reduced childcare fees. Families or couples with high trust in politicians election promises could potentially decide to have an additional child already when the Social Democrats won the election in the autumn in 1998. ${ }^{16}$ Taking the nine-month gestation period into account, July 1999 is in that case when we can expect to register births that are induced by the reform. If households on the other hand did not believe that the reform would be implemented until the reform bill was being prepared, the first births affected by the reform would be in July 2000. In 2000 the decision was made at the central level to implement the reform, but it was still voluntary for municipalities to implement the capped fee-schedules and it was not until the end of 2001 that most local governments made the final decisions to implement the reform. Hence, it is possible that it was not until July 2002 that we can start to observe births affected by the reform. Most likely, some types of households reacted early whereas other types reacted late.

In order to account for the uncertainty about when households react, we estimate a reform effect for each year before and after the reform. Doing this, we are able to trace the dynamic response of household fertility to the reform process. Hence, we estimate a model where we first calculate the price change for each household type in year $t$, given the old and reformed fee schedule in each municipality and then inter-act this price change with a time dummy, $\tau_{t}$,

\footnotetext{
${ }^{16}$ Elinder et al (2008) show that the election promise was credible enough to affect families' voting behavior.
} 
producing $T$ - $1 \beta$-estimates, where $T$ is the number of years of data. The equation we estimate is hence given by

$$
\Delta \text { Child }_{j m t}=\alpha+\beta \tau_{t} \Delta P_{m}\left(Z_{j}\right)+\tau_{t}+\Delta X_{j m t}+\Delta \varepsilon_{j m t},
$$

where $\Delta$ Child $_{j m t}$ is the change in the probability that a household of type $j$ in municipality $m$ will have an additional child in a defined time window and $\Delta X_{j m t}$ is the change in mean characteristics that do not determine childcare fees, but are important for fertility decisions, in the household type - municipality cell. ${ }^{17}$ In particular, we include maternal age and education as a means to improve efficiency. In measuring $\Delta$ Child $_{j m t}$ we define a set of 12-month time windows starting in July in each of the years after we observe households and ending in June the next year. Hence, household characteristics are measured in December of year $t$ for $t=[1, \ldots, T]$, childcare fees are computed for January of year $t+1$ onwards, and fertility behavior is measures from July of year $t+1$ through June $t+2$.

\subsection{Data}

We use data from The Institute for Labour Market Policy Evaluation (IFAU), Statistics Sweden and the Swedish Public Employment Service. Information on fee schedules comes from a survey of municipal childcare charge tariffs conducted by IFAU. ${ }^{18}$ Information on household characteristics and fertility comes from register data from Statistics Sweden, and data on the local unemployment rate from the Swedish Public Employment Service.

We sample all couples in which the woman is 20-45 years old in each year 1996-2003, since these are the women "at risk" of being affected by the price change. Thus, we define household characteristics 1996 and births July 1997 to July 1998, characteristics 1997 and births July 1998 to July 1999, and so forth. Each year we exclude women that gave birth in the previous 6 months, i.e. Jan-June since these are not at risk of having another child. The selected time period implies that we have two years of data that are undoubtedly unaffected by the reform. This makes it possible to perform one true placebo-experiment, comparing

\footnotetext{
${ }^{17}$ Note that the model is estimated on first differences at the household type - municipal level which implies that any level effects are differences out.

${ }^{18}$ IFAU collected childcare fee data via an email request sent to all Swedish municipalities asking for exact formulas used to calculate prices in 2001-04. Information about the exact fee structure from 220 of Sweden's 290 municipalities was received. Comparing the pre-reform childcare costs for a number of type families in the municipalities that responded with those of the municipalities that did not respond (available in Skolverket, 1999), we conclude that the costs are very similar, which implies that we need not worry about selection based on a specific type of municipality.
} 
changes in fertility for the sample of households 1996 to 1997 to changes in behavior for the 1997 and 1998 samples. The reason for not going further back in time is that the pre-reform fee schedules collected through the survey were those that were in place in 2001, and we do not have information about the schedules actually in place prior to this year. Therefore, the further back in time we go, the larger will the measurement error in our price measure be.

Because Swedish register data does not code cohabiting couples without common children as household units, our sample excludes unmarried women without children, single mothers, and cohabiting unmarried mothers whose partners are not the fathers of their children. For these women, we are unable to obtain a correct measure of household income because we cannot identify the potential father. ${ }^{19}$ As a result, our analysis of first births is restricted to married couples. This is unfortunate because a high fraction of Swedish first-borns, more than two thirds, are born out of wedlock (www.SCB.se). The results we present for childless women are therefore not representative of the population of childless women because married couples are likely to differ from unmarried couples in several respects. It is, however, not clear if they should be expected to be more or less sensitive to changes in childcare fees than unmarried couples. Our analysis for higher order births covers more or less the full Swedish population.

For the households in our sample, we obtain register-based information on the woman's age and education, the annual income for the woman and her partner, and the number of children living in the household and their respective ages. We also obtain register information on if and when the women give birth.

\subsection{Computing childcare costs and birth rates}

As was described above, childcare charges depend on a limited number of observable household characteristics. Given knowledge of these characteristics from register data, we compute the present values of households' exact future childcare costs. We compute the marginal cost of having one additional child by calculating the present value of total remaining cost of childcare assuming that the newborn will be enrolled in childcare at age one

\footnotetext{
${ }^{19}$ We have tried to impute household income for these unmarried childless women using predictions from the sample for which we observe both parents. Because we were unable to replicate our results for the married women using predicted household income, we judge that the results for unmarried childless women are too speculative and uncertain.
} 
and continue in childcare until age ten. ${ }^{20}$ We expect a negative effect of the marginal childcare cost on households' fertility decisions.

For households that already have children attending childcare, the reform also implied an income effect, since it became cheaper to have these children in childcare. We therefore also compute a measure of the present value of total remaining cost of childcare for the children already present in the household assuming that each child will be enrolled in full-time care until it reaches the age of ten (cost of presently enrolled).

Table 3 presents the present value of the remaining childcare costs according to the preand post-reform fee schedules for a marginal additional child $(\mathrm{MC}=$ marginal cost $)$ and the children already present in households with children ( $\mathrm{SQ}=$ status quo) (Columns 1 and 2) and for having a first child for households without children ( $\mathrm{MC}=$ marginal cost) (Column 3) for the true reform year, 2002. When computing pre-reform costs, we apply the pre-reform fee schedules reported in survey responses. ${ }^{21}$ Post-reform costs are computed using the reform fee schedule as it was stipulated by central government, thus assuming that the capped fees were implemented in the same way across the country.

As is clear from Table 3, comparing the pre-reform and post-reform costs for childcare, these decreased dramatically due to the reform. On average, the net present value of remaining childcare costs decreased by more than 50 percent. The drop in the standard deviation of childcare costs also shows that the variation in fees across households decreased radically when the reformed national fee schedule replaced local fee schedules.

\footnotetext{
${ }^{20}$ Note that we do not observe whether children attend childcare or for how many hours they do so. The cost measure we calculate is based on the assumption that everyone attends childcare and after-school care full-time. As a sensitivity test, we will also calculate the costs assuming that children do not attend after-school care. We have further assumed that the families discount future costs exponentially with the discount rate 0.05 . Within reasonable limits, the results are not sensitive to the choice of discount factor.

${ }^{21}$ The information collected by IFAU pertains to the fee schedules as they were in 2001. Information on prices scheduled prior to 2001 is not available, but the survey information suggests that there were no major changes in local fee schedules in the years prior to the reform. As a result, we use the fee schedule for 2001 to compute what the household pre-reform fee was in the years prior to 2001. Although inflation was minor during these years, we have denominated household incomes in 2001 prices using a consumer price index in order to achieve comparability across years.
} 
Table 3 Present value of pre-reform and post-reform remaining childcare costs in SEK '000s.

\begin{tabular}{l|ccc}
\hline & \multicolumn{2}{|c}{ Households with children } & $\begin{array}{c}\text { Households without } \\
\text { children }\end{array}$ \\
& $\begin{array}{c}\text { Marginal cost of } \\
\text { additional child, MC }\end{array}$ & $\begin{array}{c}\text { Cost of presently } \\
\text { enrolled children, SQ }\end{array}$ & $\begin{array}{c}\text { Marginal cost of } \\
\text { first child, MC }\end{array}$ \\
\hline Pre-reform fee- & 142.56 & 118.11 & 193.25 \\
schedules & $(67.75)$ & $(86.34)$ & $(59.96)$ \\
\hline Post-reform fee- & 64.76 & & 80.64 \\
schedules & $(22.19)$ & $(36.79)$ & $(21.41)$ \\
\hline
\end{tabular}

Note: Average values. Standard deviations in parenthesis. Household characteristics from 2000. When calculating present values, we have used a discount rate of 0.02 .

The capping of childcare charges implied that the largest cost cuts occurred for households that initially had high childcare costs. In order to encourage a better understanding of which type of households experienced the largest cost reductions, Table 4 shows changes in total remaining childcare costs (marginal cost + cost for presently enrolled) at different parity and household income levels. Note that the largest cost changes occurred for well-off families that already had two children, while low-income households without children received a much smaller reduction in childcare cost. Although the within-family variation in childcare cost changes was smaller for families with low incomes or few children, Table 4 also illustrates that the reform introduced substantial variation in costs reductions for households with similar incomes and the same number of children. 
Table 4 Change in present value of total remaining childcare cost for a household experiencing the birth of one additional child, SEK '000s.

\begin{tabular}{lccc}
\hline Parity & \multicolumn{3}{c}{ Household income } \\
\hline & Low & Medium & High \\
No children & 76.24 & 117.29 & 135.58 \\
& $(28.24)$ & $(29.78)$ & $(41.51)$ \\
One child & 51.45 & 90.09 & 118.40 \\
& $(31.98)$ & $(41.89)$ & $(51.79)$ \\
Two or more & 43.65 & 78.09 & 101.52 \\
& $(29.74)$ & $(39.21)$ & $(48.50)$
\end{tabular}

Note: Average values. Standard deviations in parenthesis. Household characteristics from 2000. Total remaining child cost $=\mathrm{MC}+\mathrm{SQ}$

\subsection{Defining household types}

The estimation strategy discussed in section 3.1.1. relies on comparisons of households that are identical with respect to all factors affecting both childcare fees and fertility but that experience different changes in childcare costs because they live in different municipalities. To achieve such a comparison, we need i) to define household types based on income, the number of children and the age of the children; and ii) to observe each household type in at least two municipalities, both before and after the reform. In defining household types, we therefore face a trade-off. The more narrowly we define household types, the more precisely is our measure of childcare costs, the smaller is the within-household variance in characteristics that determine childcare charges and, hence, the more truly random is the within-household variation in childcare costs. The drawback of defining household types too narrowly is that we are less likely find matches over time for the same household type in at least two municipalities. Hence, the more precise are our household types, the less representative is the sample used for estimation.

This problem is fruitfully illustrated by the example of household income. Household income is a continuous variable, and it is therefore not possible to perform an unconstrained match. Doing so would prevent us from finding matches for most of our household types. Instead, we use monthly income spans of SEK 1,000 in 2002 prices. When attempting to 
match the exact age of each child, a similar problem arises. Instead, we choose to define household types by the number of children under the age of 10, the exact age of the youngest child and the age category of each of the next three youngest children, and the household's monthly income span. We consider the four youngest children in the household because only a few municipalities before the reform (and none after) charged fees for the fifth child or any thereafter. The age categories are defined in line with the typical age categories determining childcare charges: 1-3, 4-5 and 6-9.

\section{Results: Effects of childcare costs on fertility}

\subsection{Baseline estimates}

There are two different groups of potential parents that are likely to be affected by the reform differently; households with children and households with no previous children. For the former group the reform has both an income and a price effect, whereas for households with no previous children there is only a price effect. We will therefore estimate the model in equation (2) for each group separately. Note that the model is estimated on first differences at the household type - municipal level which implies that any level effects are differences out. Year fixed effects in this context imply that we identify fertility effects of changes in child care costs on deviations from average year to year changes in fertility, i.e. deviations from trend.

Table 5 presents the result for families without children. ${ }^{22}$ First we inspect the estimate on the first row, $\triangle \mathrm{MC} \_1997$. Since the capped fee reform was first presented as an election promise in 1998 there could be no effect of the reform for the first year in our estimations. The estimate for $\Delta \mathrm{MC}_{-} 1997$ is small and insignificant, and suggests that there are no underlying trends in the specification. This specification will be our preferred one.

\footnotetext{
${ }^{22}$ This sample only includes married couples, since register data does not allow us to capture cohabiting couples without common children.
} 
Table 5 Child care costs and fertility - Households without children

\begin{tabular}{|c|c|}
\hline Variables & $\Delta$ Child births per 1,000 women \\
\hline$\Delta \mathrm{MC} \_1997$ & $\begin{array}{l}-0.00673 \\
(0.0570)\end{array}$ \\
\hline$\Delta \mathrm{MC} \_1998$ & $\begin{array}{c}-0.108 \\
(0.0698)\end{array}$ \\
\hline$\Delta \mathrm{MC} \_1999$ & $\begin{array}{l}-0.0795 \\
(0.0632)\end{array}$ \\
\hline$\Delta \mathrm{MC} \_2000$ & $\begin{array}{c}-0.126 * * \\
(0.0634)\end{array}$ \\
\hline$\Delta \mathrm{MC} \_2001$ & $\begin{array}{l}-0.0342 \\
(0.0639)\end{array}$ \\
\hline$\Delta \mathrm{MC} \_2002$ & $\begin{array}{l}-0.0385 \\
(0.0604)\end{array}$ \\
\hline$\Delta \mathrm{MC} \_2003$ & $\begin{array}{l}-0.0468 \\
(0.0687)\end{array}$ \\
\hline$\Delta$ Woman's age & $\begin{array}{c}-15.91 * * * \\
(0.314)\end{array}$ \\
\hline$\Delta$ University degree & $\begin{array}{c}53.33 * * * \\
(4.667)\end{array}$ \\
\hline$\Delta$ Unemployment & $\begin{array}{l}-1.185 \\
(2.586)\end{array}$ \\
\hline Year FE & Yes \\
\hline $\begin{array}{l}\text { F-test } \Delta M C_{-} 1998-\Delta M C \_2003 \\
\text { (p-value) } \\
\text { Observations } \\
\text { R-squared }\end{array}$ & $\begin{array}{c}20.68 \\
(0.000) \\
44,876 \\
0.117\end{array}$ \\
\hline
\end{tabular}

Note: Robust standard errors clustered at the municipal level in parenthesis. * indicates significance at the $10 \%$ level, $* *$ at the $5 \%$ level and $* * *$ at the $1 \%$ level. Household types are defined by household monthly income span of 1,000 SEK

Turning to the other estimates we see that for the years 1998, 1999 and 2000 the point estimates are in the range $-0.108--0.126$, indicating that higher marginal childcare costs do indeed decrease fertility. In other words, the reform induced reduction in child care costs lead to increased fertility for couples without children. However, the only statistically significant point estimate is the one for 2000, suggesting that households reacted more consistently when the reform was passed in the parliament (see Table 2). Testing the joint significance of the annual effects gives a highly significant F-statistic, suggesting that there is a positive effect on first births of reducing childcare prices. A childless couple facing an average reduction in fees of SEK 111,000 (see Table A2) increased fertility by 9.8 percent compared to the average rate 
in 1998. (111x0.126/142.7). This effect is indeed large, but the average reduction of childcare cost was also large and corresponded to roughly a quarter of one year of household earnings for average childless couples. The magnitude of the effect implies that a 10,000 US dollar reduction in the present value of the future marginal child care costs would increase fertility rates with 5.7 percent. The pattern of negative (but insignificant) estimates already for the years 1998 and 1999 may suggest that a subgroup of the households anticipated the reform already when the Social Democrats won the election and reacted by having children.

The control variables; the woman's age and education level are highly significant. Younger women are more likely to have children than older women and more highly educated women with a university degree are more likely to have a child than women with lower education. It is worth noting that we are making the comparison between more and less educated women or younger and older women, given household income. It is possible that more educated women that belong to the same household type as less educated women are more family oriented (as opposed to career oriented), explaining why higher education is associated with higher fertility. Changes in local unemployment do however not seem to affect families' fertility decisions. The estimated coefficient has the expected negative sign but is not statistically significant.

Next we turn to the households who already have children in childcare age. The results are presented in Table 6 below. Column (1) presents the result from the specification given by equation (2), i.e. a difference-in-difference specification at the household type $\times$ municipality level. Since the reform was first mentioned in the election campaign 1998 we should not expect to find any effect of the reform for the first year in our estimations (i.e. $\Delta$ MC_1997 and $\Delta$ SQ_1997). However, as is clear from the results, we do find statistically (and economically) significant coefficients on the variables capturing the future changes in prices (both for marginal cost and the "status quo"-costs). These estimates suggest a presence of preexisting time trends in the birth rates of household types that that correlate with future price changes. In column (2) we therefore estimate a model where we control for time-specific household type-effects. ${ }^{23}$ Doing this, we find that the estimates for the pre-reform year 1997 are both statistically and economically insignificant. The specification in column (2) will therefore be our preferred specification.

\footnotetext{
${ }^{23}$ We have also elaborated with a linear household-type trend, and a linear municipality trend respectively. Doing this, we still find an effect the first year, and we therefore reject those specifications. These results are available upon request.
} 
Turning to the parameter estimates for effects of a change in marginal cost on fertility in column (2) there is a marginally significant negative effect in 1999. This indicates that households with children reacted slightly earlier than households without children, i.e. when the proposal was prepared. The size of the parameter estimate is -0.081 , which is a smaller effect than for households without children. If we compare the corresponding impact of the average reduction in child care fees of SEK 77,000 to the pre-reform average birth rate for families with children the impact of the reform was to increase births by 9 percent (77x0.087/74.4). This effect is similar in magnitude to the effect for childless couples although their average reduction in childcare cost was smaller relative to household annual earnings for families and corresponded to about a fifth of a year's earnings. Note that the estimates for the other years in which households could potentially have reacted, are not going in the same (negative) direction. In fact, a test of the joint significance of the effect of cost changes on fertility for 1998-2003 shows that there is no statistically significant overall effect. A possible interpretation is that the child care fee reform had an impact on the timing of births, causing families to have an additional child slightly earlier than planned, but that there was no effect on total fertility. For families with children, the reform reduced childcare costs also for the children already enrolled, creating a positive income transfer. Our estimates (the $\Delta$ SQ-estimates) indicate that there are no statistically significant income-effects on fertility behavior induced by the reform. There is, however, a positive estimate of a nonnegligible magnitude for the year 1998 suggesting, if anything, a possible presence of negative income effects. 
Table 6 Childcare costs and fertility - Households with children

\begin{tabular}{|c|c|c|}
\hline Variables & \multicolumn{2}{|c|}{$\Delta$ Child births per 1,000 women } \\
\hline$\Delta \mathrm{MC} \_1997$ & $\begin{array}{c}0.0504 * * * \\
(0.0177)\end{array}$ & $\begin{array}{c}-0.000905 \\
(0.0340)\end{array}$ \\
\hline$\Delta \mathrm{MC} \_1998$ & $\begin{array}{c}0.0373 * * \\
(0.0177)\end{array}$ & $\begin{array}{c}0.0115 \\
(0.0374)\end{array}$ \\
\hline$\Delta M C \_1999$ & $\begin{array}{c}-0.0339 * \\
(0.0188)\end{array}$ & $\begin{array}{l}-0.0811^{*} \\
(0.0418)\end{array}$ \\
\hline$\Delta \mathrm{MC} \_2000$ & $\begin{array}{l}0.0359 * \\
(0.0186)\end{array}$ & $\begin{array}{c}0.0474 \\
(0.0314)\end{array}$ \\
\hline$\Delta \mathrm{MC} \_2001$ & $\begin{array}{l}-0.00818 \\
(0.0165)\end{array}$ & $\begin{array}{l}-0.00163 \\
(0.0256)\end{array}$ \\
\hline$\Delta \mathrm{MC} \_2002$ & $\begin{array}{l}0.219 * * * \\
(0.0287)\end{array}$ & $\begin{array}{l}-0.0299 \\
(0.0256)\end{array}$ \\
\hline$\Delta \mathrm{MC} \_2003$ & $\begin{array}{c}0.0217 \\
(0.0165)\end{array}$ & $\begin{array}{l}0.00325 \\
(0.0318)\end{array}$ \\
\hline$\Delta S Q \_1997$ & $\begin{array}{c}-0.0775 * * * \\
(0.0161)\end{array}$ & $\begin{array}{l}-0.0119 \\
(0.0424)\end{array}$ \\
\hline$\Delta S Q \_1998$ & $\begin{array}{c}0.0223 \\
(0.0210)\end{array}$ & $\begin{array}{c}0.0871 \\
(0.0544)\end{array}$ \\
\hline$\Delta S Q \_1999$ & $\begin{array}{c}-0.0393 * * \\
(0.0153)\end{array}$ & $\begin{array}{c}0.0105 \\
(0.0364)\end{array}$ \\
\hline$\Delta S Q \_2000$ & $\begin{array}{l}-0.00511 \\
(0.0184)\end{array}$ & $\begin{array}{l}-0.00452 \\
(0.0392)\end{array}$ \\
\hline$\Delta S Q \_2001$ & $\begin{array}{c}-0.0459 * * * \\
(0.0175)\end{array}$ & $\begin{array}{l}-0.0429 \\
(0.0438)\end{array}$ \\
\hline$\Delta S Q \_2002$ & $\begin{array}{c}-0.241 * * * \\
(0.0235)\end{array}$ & $\begin{array}{c}0.0289 \\
(0.0479)\end{array}$ \\
\hline$\Delta S Q \_2003$ & $\begin{array}{l}0.00392 \\
(0.0163)\end{array}$ & $\begin{array}{l}0.00110 \\
(0.0403)\end{array}$ \\
\hline$\Delta$ Woman's age & $\begin{array}{c}-8.332 * * * \\
(0.110)\end{array}$ & $\begin{array}{c}-8.203 * * * \\
(0.112)\end{array}$ \\
\hline$\Delta$ University degree & $\begin{array}{c}25.84 * * * \\
(0.877)\end{array}$ & $\begin{array}{c}26.07 * * * \\
(0.877)\end{array}$ \\
\hline$\Delta$ Unemployment & $\begin{array}{l}-0.298 \\
(0.597)\end{array}$ & $\begin{array}{l}-0.135 \\
(0.626)\end{array}$ \\
\hline Year FE & Yes & Yes \\
\hline Household typexyear FE & No & Yes \\
\hline F-test $\triangle M C \_1998-$ & & 1.22 \\
\hline$\Delta \mathrm{MC} \_2003$ (p-value) & & $(0.2708)$ \\
\hline $\begin{array}{l}\text { F-test } \Delta \text { SQ_1998- } \\
\Delta \text { SQ } 2003 \text { (p-value) }\end{array}$ & & $\begin{array}{c}1.69 \\
(0.1950)\end{array}$ \\
\hline Observations & 628,036 & 628,036 \\
\hline R-squared & 0.023 & 0.069 \\
\hline
\end{tabular}

Note: Robust standard errors clustered at the municipal level in parenthesis. * indicates significance at the $10 \%$ level, $* *$ at the $5 \%$ level and $* * *$ at the $1 \%$ level. Household types are defined by the number of children under the age of 10, the exact age of the youngest child, the age category (ages 0-3, 4-5, 6-9) of the next three youngest children and a household monthly income span of 1,000 SEK. 


\subsection{Robustness tests}

In the analysis above, we have let "data speak" in the sense that we have accepted the specifications of the models if the placebo-results have shown zero-effects. For households without children, this implied accepting the DD-specification without additional trends. For households with children, zero-effects in the placebo tests required a specification with household-type time-specific effects. The identification hence relies on the assumption that such effects are not important for households without children and that there are no underlying municipal trends. We next conduct a number of checks introducing different types of trends to test the robustness of our results. However, one should be aware that including trends does not come without a cost; the more trends we allow for, less of the identifying variation is used in the estimations.

According to the results in Table 5 households without children reacted to the price change by increasing fertility. The results presented in Table 7 in columns (1) and (2) include household typexyear fixed effects and municipality specific trends, respectively. Including household type and time fixed effects reduces the estimates somewhat and increases the standard errors substantially. Although the estimates are no longer statistically significant the general picture is the same as in the preferred baseline specification presented in Table 5. When including municipality specific trends, the effect of marginal childcare costs on fertility becomes stronger, and also the estimates for 1998 and 1999 are (marginally) statistically significant on the 10 percent level.

Because one may worry that the results are driven by endogenous residence decisions we next re-estimate our preferred specifications excluding households that either recently moved to the municipality or moved from the municipality in the year of investigation. The results presented in column (3) show that this does not affect the results.

Finally, when calculating the changes in childcare fees we have assumed that all children in the household attend full-time childcare until 10 years of age. Enrollment rates however fall somewhat as children get older, as is also evident from Figure 1. We have therefore recalculated the changes in childcare fees assuming that children only attend childcare until the age of 6. The resulting estimates that are presented in column (4) show more or less the same pattern as the baseline results.

The robustness checks in Table 7 support our conclusion that the childcare fee reform induced married couples with no former children to increase their fertility. 
Table 7 Robustness checks - Households without children

\begin{tabular}{|c|c|c|c|c|}
\hline Variables & \multicolumn{4}{|c|}{$\Delta$ Child births per 1,000 women } \\
\hline$\Delta M C_{-} 1997$ & $\begin{array}{c}(1) \\
0.0286 \\
(0.0890)\end{array}$ & $\begin{array}{c}(2) \\
-0.0303 \\
(0.0573)\end{array}$ & $\begin{array}{c}(3) \\
-0.0123 \\
(0.0579)\end{array}$ & $\begin{array}{c}(4) \\
-0.0967 \\
(0.105)\end{array}$ \\
\hline$\Delta \mathrm{MC} \_1998$ & $\begin{array}{l}-0.0519 \\
(0.0895)\end{array}$ & $\begin{array}{l}-0.131^{*} \\
(0.0707)\end{array}$ & $\begin{array}{l}-0.0928 \\
(0.0721)\end{array}$ & $\begin{array}{l}-0.0971 \\
(0.129)\end{array}$ \\
\hline$\Delta M C_{-} 1999$ & $\begin{array}{l}-0.0549 \\
(0.0838)\end{array}$ & $\begin{array}{l}-0.103^{*} \\
(0.0613)\end{array}$ & $\begin{array}{l}-0.0893 \\
(0.0664)\end{array}$ & $\begin{array}{l}-0.0782 \\
(0.0950)\end{array}$ \\
\hline$\Delta \mathrm{MC} \_2000$ & $\begin{array}{l}-0.0695 \\
(0.0778)\end{array}$ & $\begin{array}{l}-0.155^{* *} \\
(0.0669)\end{array}$ & $\begin{array}{l}-0.140 * * \\
(0.0676)\end{array}$ & $\begin{array}{c}-0.239 * * \\
(0.106)\end{array}$ \\
\hline$\Delta \mathrm{MC} \_2001$ & $\begin{array}{l}0.00939 \\
(0.0856)\end{array}$ & $\begin{array}{l}-0.0614 \\
(0.0624)\end{array}$ & $\begin{array}{l}-0.0287 \\
(0.0666)\end{array}$ & $\begin{array}{l}-0.108 \\
(0.110)\end{array}$ \\
\hline$\Delta \mathrm{MC} \_2002$ & $\begin{array}{l}-0.00803 \\
(0.0753)\end{array}$ & $\begin{array}{l}-0.0651 \\
(0.0610)\end{array}$ & $\begin{array}{l}-0.0488 \\
(0.0639)\end{array}$ & $\begin{array}{l}-0.0579 \\
(0.0932)\end{array}$ \\
\hline$\Delta \mathrm{MC} \_2003$ & $\begin{array}{l}0.00819 \\
(0.0914)\end{array}$ & $\begin{array}{l}-0.0709 \\
(0.0688)\end{array}$ & $\begin{array}{l}-0.0673 \\
(0.0678)\end{array}$ & $\begin{array}{l}-0.0595 \\
(0.108)\end{array}$ \\
\hline Control variables & Yes & Yes & Yes & Yes \\
\hline Year FE & Yes & Yes & Yes & Yes \\
\hline $\begin{array}{l}\text { Household typexyear } \\
\text { FE }\end{array}$ & Yes & No & No & No \\
\hline Municipality trend & No & Yes & No & No \\
\hline Excluding movers & No & No & Yes & No \\
\hline $\begin{array}{l}\text { Age of children } \\
\text { attending childcare }\end{array}$ & $1-9$ & $1-9$ & $1-9$ & $1-5$ \\
\hline $\begin{array}{l}\text { F-test } \Delta M C_{-} 1998- \\
\Delta M C_{-} 2003 \\
\text { (p-value) }\end{array}$ & $\begin{array}{c}1.84 \\
(0.1766)\end{array}$ & $\begin{array}{c}35.20 \\
(0.0000)\end{array}$ & $\begin{array}{c}22.33 \\
(0.0000)\end{array}$ & $\begin{array}{c}18.04 \\
(0.0000)\end{array}$ \\
\hline $\begin{array}{l}\text { Observations } \\
\text { R-squared }\end{array}$ & $\begin{array}{c}44,876 \\
0.145\end{array}$ & $\begin{array}{c}44,876 \\
0.119 \\
\end{array}$ & $\begin{array}{c}44,876 \\
0.117 \\
\end{array}$ & $\begin{array}{c}43,417 \\
0.118 \\
\end{array}$ \\
\hline
\end{tabular}

Note: Robust standard errors clustered at the municipal level in parenthesis. * indicates significance at the $10 \%$ level, ** at the 5\% level and *** at the $1 \%$ level. Household types are defined by household monthly income span of 1,000 SEK. Control variables are woman's age and education, and local unemployment.

Next, we turn to households that already have children in ages eligible for subsidized child care and test the robustness of the results that were presented in Table 6. Column (1) in Table 8 presents the results when including municipality specific trends to the baseline specification. This does not change the results. Column (2) shows the preferred specification from Table 6 but excluding movers. This does not change the results found above; there is a price effect in 1999 of the expected sign, but when summing the effect between 1998-2003 there is no statistically significant effect. Column (3) shows the same specification as column 
(2), but without excluding movers, and assuming that children aged 6 to 9 are not enrolled in childcare.

Table 8 Robustness checks - Households with children

\begin{tabular}{|c|c|c|c|}
\hline Variables & \multicolumn{3}{|c|}{$\Delta$ Child births per 1,000 women } \\
\hline \multirow{3}{*}{$\Delta \mathrm{MC} \_1997$} & (1) & $(2)$ & (3) \\
\hline & 0.00243 & 0.00490 & -0.0650 \\
\hline & $(0.0344)$ & $(0.0335)$ & $(0.0450)$ \\
\hline \multirow[t]{2}{*}{$\Delta \mathrm{MC} \_1998$} & 0.0126 & 0.0138 & 0.0460 \\
\hline & $(0.0372)$ & $(0.0380)$ & $(0.0394)$ \\
\hline \multirow{2}{*}{$\Delta \mathrm{MC}_{-} 1999$} & $-0.0795^{*}$ & $-0.0725^{*}$ & -0.0871 \\
\hline & $(0.0425)$ & $(0.0413)$ & $(0.0606)$ \\
\hline \multirow[t]{2}{*}{$\Delta \mathrm{MC} \_2000$} & 0.0493 & 0.0411 & 0.0495 \\
\hline & $(0.0317)$ & $(0.0295)$ & $(0.0504)$ \\
\hline \multirow[t]{2}{*}{$\Delta \mathrm{MC} \_2001$} & 0.000105 & 0.00402 & -0.0220 \\
\hline & $(0.0264)$ & $(0.0237)$ & $(0.0480)$ \\
\hline \multirow{2}{*}{$\Delta \mathrm{MC} \_2002$} & -0.0284 & -0.0371 & -0.0116 \\
\hline & $(0.0277)$ & $(0.0260)$ & $(0.0398)$ \\
\hline \multirow{2}{*}{$\Delta \mathrm{MC} \_2003$} & 0.00487 & -0.00303 & -0.00160 \\
\hline & $(0.0331)$ & $(0.0326)$ & $(0.0501)$ \\
\hline \multirow[t]{2}{*}{$\Delta S Q \_1997$} & -0.00599 & -0.00114 & 0.0427 \\
\hline & $(0.0430)$ & $(0.0431)$ & $(0.0640)$ \\
\hline \multirow[t]{2}{*}{$\Delta S Q \_1998$} & 0.0918 & 0.0813 & 0.124 \\
\hline & $(0.0556)$ & $(0.0541)$ & $(0.0798)$ \\
\hline \multirow[t]{2}{*}{$\Delta S Q \_1999$} & 0.0164 & -0.00400 & -0.0102 \\
\hline & $(0.0366)$ & $(0.0369)$ & $(0.0691)$ \\
\hline \multirow[t]{2}{*}{$\Delta S Q \_2000$} & 0.000367 & 0.00502 & 0.0224 \\
\hline & $(0.0391)$ & $(0.0398)$ & $(0.0798)$ \\
\hline \multirow[t]{2}{*}{$\Delta S Q \_2001$} & -0.0387 & -0.0544 & -0.0967 \\
\hline & $(0.0457)$ & $(0.0440)$ & $(0.0878)$ \\
\hline \multirow[t]{2}{*}{$\Delta S Q \_2002$} & 0.0327 & 0.0260 & 0.0800 \\
\hline & $(0.0472)$ & $(0.0500)$ & $(0.0946)$ \\
\hline \multirow[t]{2}{*}{$\Delta S Q \_2003$} & 0.00509 & -0.00644 & -0.0439 \\
\hline & $(0.0415)$ & $(0.0427)$ & $(0.0745)$ \\
\hline Control variables & Yes & Yes & Yes \\
\hline Year FE & Yes & Yes & Yes \\
\hline Household typexyear FE & Yes & Yes & Yes \\
\hline Municipality trend & Yes & No & No \\
\hline Excluding movers & No & Yes & No \\
\hline $\begin{array}{l}\text { Age of children attending } \\
\text { childcare }\end{array}$ & $1-9$ & $1-9$ & $1-5$ \\
\hline F-test $\Delta \mathrm{MC}_{-} 1998-$ & 0.41 & 1.36 & 1.66 \\
\hline $\begin{array}{l}\Delta \mathrm{MC}_{2} 2003 \\
\text { (p-value) }\end{array}$ & $(0.5230)$ & $(0.2455)$ & $(0.1992)$ \\
\hline F-test $\Delta$ SQ_1998- & 1.93 & 0.57 & 1.26 \\
\hline$\Delta \mathrm{SQ}_{-} 2003$ & $(0.1662)$ & $(0.4525)$ & $(0.2630)$ \\
\hline (p-value) & & & \\
\hline Observations & 628,036 & 613,208 & 628,036 \\
\hline R-squared & 0.069 & 0.070 & 0.069 \\
\hline
\end{tabular}


Note: Robust standard errors clustered at the municipal level in parenthesis. * indicates significance at the $10 \%$ level, ** at the $5 \%$ level and $* * *$ at the $1 \%$ level. Household types are defined by the number of children under the age of 10, the exact age of the youngest child, the age category (ages 0-3, 4-5, 6-9) of the next three youngest children and a household monthly income span of 1,000 SEK. Control variables are woman's age and education, and local unemployment.

\subsection{Heterogeneous effects with respect to the number of children}

From our preferred specification in Table 6 we concluded that there is a marginally significant price effect and an insignificant income effect working in opposite directions for families with children. The F-tests of the total effects of the price and income effects of the reform, however, suggested that it did not affect total fertility. Thus, if anything, the change in the marginal cost made families change the timing of their demand for children. In the group "families with children" households differ with respect to how many children they have before the reform and it is possible that effects differ by parity. We therefore allow the parameter estimates to differ for families with only one child and families with two or more children. Column (1) presents the results from the preferred baseline model, column (2) includes municipality specific trends and (3) excludes movers. The results confirm that households do in fact react differently to the reform depending on parity. Interestingly, households with one child seem to have reacted to the lower marginal costs induced by the reform by postponing their second child one year (there is positive effect in 1998 and a negative effect in 1999). Thus they postponed having children until the proposal was prepared in the government. For this group the coefficient estimates suggest a presence of a negative income effect but it not significant because standard errors are large. Also, F-tests show that there are no significant overall effects on second births of reducing child care costs.

For households with two or more children, on the other hand, there is no sign of postponing births and instead a weakly statistically significant effect for 1998 suggesting that expectations of reduced fees increased fertility. A test of joint significance of the price variables 1998-2003 also suggests a marginally significant total effect. For families with two or more children there is a significant negative income effect 1998, which is not completely cancelled out by effects in the opposite direction later on, as suggested by a marginally significant F-test. For this group of families the average reduction in marginal childcare costs amounted to SEK 71,000, or 18 percent of a year's family earnings, which implies that the reform increased fertility with some 14.5 per cent $(71 \times 0.07 / 34.3)$. For these families the reform induced positive income shock amounted to on average SEK 74,000, which corresponds to 19 percent of annual earnings. The income effect estimate of 0.099 implies a 
negative effect on fertility in the order of magnitude of 22 percent $(74 x 0.99 / 34)$. Columns 2 and 3 show that the results are not very sensitive to the inclusion of municipality trends, but the overall income effect is no longer significant when excluding movers.

Table 9 Childcare costs and fertility - heterogeneous effects with respect to parity

\begin{tabular}{|c|c|c|c|}
\hline Variables & \multicolumn{3}{|c|}{$\Delta$ Child births per 1,000 women } \\
\hline$\Delta \mathrm{MC1} 1997$ & -0.00431 & 0.000324 & $\begin{array}{r}-0.00133 \\
(0.0475)\end{array}$ \\
\hline$\Delta \mathrm{MC1} 1998$ & $\begin{array}{l}0.0722 * \\
(0.0412)\end{array}$ & $\begin{array}{l}0.0745^{*} \\
(0.0415)\end{array}$ & $0.0835 * *$ \\
\hline$\Delta \mathrm{MC1} 1999$ & $\begin{array}{c}-0.129 * * \\
(0.0562)\end{array}$ & $\begin{array}{c}-0.127 * * \\
(0.0568)\end{array}$ & $\begin{array}{c}-0.120 * * \\
(0.0552)\end{array}$ \\
\hline$\Delta \mathrm{MC1} \_2000$ & $\begin{array}{c}0.0548 \\
(0.0501)\end{array}$ & $\begin{array}{c}0.0575 \\
(0.0503)\end{array}$ & $\begin{array}{c}0.0429 \\
(0.0475)\end{array}$ \\
\hline$\Delta \mathrm{MC1} \_2001$ & $\begin{array}{c}-0.0234 \\
(0.0361)\end{array}$ & $\begin{array}{c}-0.0208 \\
(0.0370)\end{array}$ & $\begin{array}{c}-0.0162 \\
(0.0344)\end{array}$ \\
\hline$\Delta \mathrm{MC1} \_2002$ & $\begin{array}{c}-0.0361 \\
(0.0309)\end{array}$ & $\begin{array}{c}-0.0337 \\
(0.0334)\end{array}$ & $\begin{array}{c}-0.0354 \\
(0.0314)\end{array}$ \\
\hline$\Delta \mathrm{MC1} \_2003$ & $\begin{array}{c}0.0559 \\
(0.0371)\end{array}$ & $\begin{array}{c}0.0591 \\
(0.0384)\end{array}$ & $\begin{array}{c}0.0483 \\
(0.0368)\end{array}$ \\
\hline$\Delta \mathrm{SQ1} 1997$ & $\begin{array}{l}0.0682 \\
(0.103)\end{array}$ & $\begin{array}{c}0.0745 \\
(0.103)\end{array}$ & $\begin{array}{l}0.0985 \\
(0.104)\end{array}$ \\
\hline$\Delta \mathrm{SQ1} 1998$ & $\begin{array}{c}0.117 \\
(0.118)\end{array}$ & $\begin{array}{c}0.124 \\
(0.121)\end{array}$ & $\begin{array}{c}0.111 \\
(0.119)\end{array}$ \\
\hline$\Delta \mathrm{SQ1} 1999$ & $\begin{array}{c}-0.0282 \\
(0.0875)\end{array}$ & $\begin{array}{c}-0.0203 \\
(0.0881)\end{array}$ & $\begin{array}{c}-0.0516 \\
(0.0869)\end{array}$ \\
\hline$\Delta \mathrm{SQ1}$ _2000 & $\begin{array}{c}0.0357 \\
(0.0983)\end{array}$ & $\begin{array}{c}0.0416 \\
(0.0976)\end{array}$ & $\begin{array}{c}0.0748 \\
(0.0979)\end{array}$ \\
\hline$\Delta \mathrm{SQ1} 12001$ & $\begin{array}{c}-0.0355 \\
(0.0991)\end{array}$ & $\begin{array}{c}-0.0310 \\
(0.101)\end{array}$ & $\begin{array}{c}-0.0462 \\
(0.0971)\end{array}$ \\
\hline$\Delta \mathrm{SQ1}$ 12002 & $\begin{array}{c}0.0751 \\
(0.121)\end{array}$ & $\begin{array}{l}0.0794 \\
(0.120)\end{array}$ & $\begin{array}{l}0.0248 \\
(0.126)\end{array}$ \\
\hline$\Delta \mathrm{SQ1} 12003$ & $\begin{array}{c}-0.178 \\
(0.138)\end{array}$ & $\begin{array}{c}-0.172 \\
(0.139)\end{array}$ & $\begin{array}{l}-0.176 \\
(0.143)\end{array}$ \\
\hline$\Delta \mathrm{MC} 2 \_1997$ & $\begin{array}{c}-0.00379 \\
(0.0293)\end{array}$ & $\begin{array}{c}-0.00244 \\
(0.0312)\end{array}$ & $\begin{array}{c}0.00387 \\
(0.0301)\end{array}$ \\
\hline$\Delta \mathrm{MC} 2 \_1998$ & $\begin{array}{c}-0.0692 * \\
(0.0392)\end{array}$ & $\begin{array}{c}-0.0700 * \\
(0.0377)\end{array}$ & $\begin{array}{c}-0.0781 * \\
(0.0414)\end{array}$ \\
\hline$\Delta \mathrm{MC} 2 \_1999$ & $\begin{array}{l}-0.0127 \\
(0.0357)\end{array}$ & $\begin{array}{l}-0.0129 \\
(0.0368)\end{array}$ & $\begin{array}{l}-0.00477 \\
(0.0371)\end{array}$ \\
\hline$\Delta \mathrm{MC} 2 \_2000$ & $\begin{array}{c}0.0341 \\
(0.0236)\end{array}$ & $\begin{array}{c}0.0348 \\
(0.0238)\end{array}$ & $\begin{array}{c}0.0347 \\
(0.0245)\end{array}$ \\
\hline$\Delta \mathrm{MC} 2 \_2001$ & $\begin{array}{c}0.0327 \\
(0.0362)\end{array}$ & $\begin{array}{c}0.0329 \\
(0.0374)\end{array}$ & $\begin{array}{c}0.0359 \\
(0.0372)\end{array}$ \\
\hline$\Delta \mathrm{MC} 2 \_2002$ & $\begin{array}{l}-0.0258 \\
(0.0375)\end{array}$ & $\begin{array}{l}-0.0258 \\
(0.0373)\end{array}$ & $\begin{array}{c}-0.0396 \\
(0.0403)\end{array}$ \\
\hline$\Delta \mathrm{MC2} 22003$ & $\begin{array}{c}-0.0508 \\
(0.0413)\end{array}$ & $\begin{array}{l}-0.0519 \\
(0.0429)\end{array}$ & $\begin{array}{c}-0.0575 \\
(0.0454)\end{array}$ \\
\hline$\triangle \mathrm{SQ} 2 \_1997$ & -0.0389 & -0.0318 & -0.0352 \\
\hline
\end{tabular}




\begin{tabular}{|c|c|c|c|}
\hline & $(0.0287)$ & $(0.0304)$ & $(0.0294)$ \\
\hline$\Delta \mathrm{SQ} 2 \_1998$ & $0.0986^{* *}$ & $0.104 * *$ & $0.0962 * *$ \\
\hline & $(0.0455)$ & $(0.0457)$ & $(0.0470)$ \\
\hline$\Delta \mathrm{SQ} 2 \_1999$ & 0.00591 & 0.0124 & -0.00516 \\
\hline & $(0.0364)$ & $(0.0368)$ & $(0.0372)$ \\
\hline$\Delta \mathrm{SQ} 2 \_2000$ & -0.0179 & -0.0123 & -0.0231 \\
\hline$\Delta \mathrm{SQ} 2$ 2001 & $\begin{array}{l}(0.0320) \\
-0.0573\end{array}$ & $\begin{array}{l}(0.0320) \\
-0.0520\end{array}$ & $\begin{array}{l}(0.0341) \\
-0.0685^{*}\end{array}$ \\
\hline$\Delta \mathrm{SQ} 2$ 2002 & $\begin{array}{c}(0.0380) \\
0.0160\end{array}$ & $\begin{array}{c}(0.0413) \\
0.0207\end{array}$ & $\begin{array}{c}(0.0399) \\
0.0272\end{array}$ \\
\hline$\Delta \mathrm{SQ} 2$ 2003 & $\begin{array}{c}(0.0501) \\
0.0495 \\
(0.0370)\end{array}$ & $\begin{array}{c}(0.0489) \\
0.0544 \\
(0.0388)\end{array}$ & $\begin{array}{c}(0.0531) \\
0.0407 \\
(0.0396)\end{array}$ \\
\hline Control variables & Yes & Yes & Yes \\
\hline Year FE & Yes & Yes & Yes \\
\hline $\begin{array}{l}\text { Household typexyear } \\
\text { FE }\end{array}$ & Yes & Yes & Yes \\
\hline Municipal trend & No & Yes & No \\
\hline Excluding movers & No & No & Yes \\
\hline F-test $\Delta M C \_1998-$ & MC1: 0.01 (0.9266) & MC1: $0.01(0.9055)$ & MC1: $0.00(0.9545)$ \\
\hline $\begin{array}{l}\triangle \mathrm{MC} 22003 \\
\text { (p-values) }\end{array}$ & MC2: 2.96 (0.0865) & MC2: $2.00(0.1591)$ & MC2: 2.99 (0.0852) \\
\hline F-test $\Delta$ SQ_1998- & SQ1: 0.01 (0.9401) & SQ1: 0.01 (0.9144) & SQ1: $0.12(0.7257)$ \\
\hline $\begin{array}{l}\triangle \mathrm{SQ} 2003 \\
\text { (p-values) }\end{array}$ & SQ2: $2.83(0.0938)$ & SQ2: $3.02(0.0836)$ & SQ2: $1.25(0.2639)$ \\
\hline Observations & 628,036 & 628,036 & 613,208 \\
\hline R-squared & 0.069 & 0.069 & 0.070 \\
\hline
\end{tabular}

Note: Robust standard errors clustered at the municipal level in parenthesis. * indicates significance at the $10 \%$ level, $* *$ at the $5 \%$ level and $* * *$ at the $1 \%$ level. Household types are defined by the number of children under the age of 10, the exact age of the youngest child, the age category (ages 0-3, 4-5, 6-9) of the next three youngest children and a household monthly income span of 1,000 SEK. Control variables are woman's age and education, and local unemployment.

\subsection{Heterogeneous effects with respect to household income}

Next, we investigate if households with different income levels respond differently to the changes in child care costs. Arguably, low income households may be more sensitive to changes in childcare costs. We estimate our baseline specifications separately for households below and above the median of household earnings for households without children and families with children respectively. The results are presented in Table 10. 
Table 10 Heterogenous effects: Household income

\begin{tabular}{|c|c|c|c|c|}
\hline Variables & & $\Delta$ Child births & r 1,000 womer & \\
\hline & Households & o children & Household & th children \\
\hline & Low income & High income & Low income & High income \\
\hline$\Delta \mathrm{MC} \_1997$ & -0.0217 & 0.119 & -0.0337 & 0.0316 \\
\hline & $(0.0850)$ & $(0.112)$ & $(0.0510)$ & $(0.0318)$ \\
\hline$\Delta \mathrm{MC} \_1998$ & -0.0318 & -0.0824 & 0.0988 & $-0.0536^{*}$ \\
\hline & $(0.124)$ & $(0.111)$ & $(0.0679)$ & (0.0299) \\
\hline$\Delta \mathrm{MC} \_1999$ & 0.142 & -0.150 & $-0.153^{* *}$ & -0.0382 \\
\hline & $(0.120)$ & $(0.107)$ & $(0.0659)$ & $(0.0350)$ \\
\hline$\Delta \mathrm{MC} \_2000$ & $-0.215^{* *}$ & 0.0184 & $0.162 * *$ & -0.00149 \\
\hline & $(0.109)$ & $(0.0956)$ & $(0.0712)$ & $(0.0239)$ \\
\hline$\Delta \mathrm{MC} \_2001$ & 0.138 & 0.0136 & 0.0398 & -0.0186 \\
\hline & $(0.118)$ & $(0.100)$ & $(0.0524)$ & $(0.0239)$ \\
\hline$\Delta \mathrm{MC} \_2002$ & $-0.235^{* *}$ & 0.0668 & 0.00934 & $-0.0484 *$ \\
\hline & $(0.107)$ & $(0.0832)$ & $(0.0635)$ & $(0.0258)$ \\
\hline$\Delta \mathrm{MC} \_2003$ & -0.0978 & 0.0239 & 0.0256 & -0.00601 \\
\hline & $(0.145)$ & $(0.0992)$ & $(0.0643)$ & $(0.0293)$ \\
\hline$\Delta \mathrm{SQ} \_1997$ & & & 0.0115 & -0.0393 \\
\hline ASO 1998 & & & $\begin{array}{l}(0.0562) \\
0.0674\end{array}$ & $\begin{array}{c}(0.0576) \\
0.811\end{array}$ \\
\hline$\Delta S Q \_1998$ & & & $\begin{array}{c}0.0674 \\
(0.0728)\end{array}$ & $\begin{array}{c}0.0811 \\
(0.0622)\end{array}$ \\
\hline$\Delta S Q \_1999$ & & & -0.000256 & 0.0448 \\
\hline & & & $(0.0563)$ & $(0.0439)$ \\
\hline$\Delta S Q \_2000$ & & & 0.0265 & -0.0553 \\
\hline & & & $(0.0650)$ & $(0.0534)$ \\
\hline$\Delta \mathrm{SQ} \_2001$ & & & -0.0264 & -0.0651 \\
\hline & & & $(0.0630)$ & $(0.0607)$ \\
\hline$\Delta$ SQ_2002 & & & -0.0399 & 0.0755 \\
\hline & & & $(0.0685)$ & $(0.0612)$ \\
\hline$\Delta$ SQ_2003 & & & $\begin{array}{l}-0.0102 \\
(0.0550)\end{array}$ & 0.00362 \\
\hline Control variables & & & Yes & Yes \\
\hline Year FE & Yes & Yes & Yes & Yes \\
\hline $\begin{array}{l}\text { Household } \\
\text { typexyear FE }\end{array}$ & No & No & Yes & Yes \\
\hline F-test $\Delta$ MC_1998- & 2.87 & 0.63 & 4.27 & 10.25 \\
\hline $\begin{array}{l}\Delta \mathrm{MC} \_2003 \\
\text { (p-value) }\end{array}$ & $(0.0918)$ & $(0.4266)$ & (0.0399) & $(0.0016)$ \\
\hline F-test $\Delta$ SQ_1998- & & & 0.03 & 1.32 \\
\hline $\begin{array}{l}\Delta \text { SQ_2003 } \\
\text { (p-value) }\end{array}$ & & & $(0.8526)$ & $(0.2518)$ \\
\hline Observations & 21,905 & 22,971 & 365,534 & 262,502 \\
\hline R-squared & 0.096 & 0.144 & 0.050 & 0.106 \\
\hline
\end{tabular}

Note: Robust standard errors clustered at the municipal level in parenthesis. * indicates significance at the $10 \%$ level, $* *$ at the $5 \%$ level and $* * *$ at the $1 \%$ level. Household types are defined by the number of children under the age of 10, the exact age of the youngest child, the age category (ages 0-3, 4-5, 6-9) of the next three youngest children and a household monthly income span of 1,000 SEK. Control variables are woman's age and education, and local unemployment. 
Columns 1 and 2 display the results for households without children. They confirm that the reduction in childcare costs had a significant impact on low income couples and insignificant impact on high income couples. Columns 3 and 4 show the results for families with children. While low income households respond strongly and have significantly more children in 1999, there are insignificant effects in the opposite direction the year before and the year after. A possible interpretation is that some low income families time births to benefit from lower costs, but that total fertility is not affected. For high income families, there is an immediate positive effect on fertility of reduced marginal costs and the absence of positive coefficients suggests that total fertility may have been affected. The estimated income effects show a similar pattern as for the entire sample, but standard errors are large and hence estimated effects are insignificant.

\subsection{Heterogeneous effects with respect to voting patterns}

The studied reform was the result of an election promise of the Social Democrats. The pattern of results so far has suggested that fertility of some groups actually responded before the election was won. It is perhaps more plausible that the election promise seemed more credible to couples and families living in municipalities dominated by Social Democrats than to other families. In order to investigate this issue further we explore if the responses to the reform vary with municipal voting patterns. To this end we estimate the preferred baseline models separately for households living in municipalities that had above or below median share of social democratic voters in the 1998 election $^{24}$. Results are presented in Table 11.

Columns 1 and 2 display results for couples without children. It is clear that couples in social democratic municipalities respond more strongly, and in particular they responded immediately to the election promise in 1998. Estimated coefficients suggest that childless couples in other municipalities respond later on, the joint test show statistical significance. For families with children there appears to be no clear difference along this political dimension. In particular, standard errors are large and we are unable to draw any strong conclusions.

\footnotetext{
${ }^{24}$ The median share of votes for the Social Democrats in the 1998 -election was 38 per cent.
} 
Table 11 Heterogenous effects: Political Voting patterns

\begin{tabular}{|c|c|c|c|c|}
\hline \multirow[t]{3}{*}{ Variables } & \multicolumn{4}{|c|}{$\Delta$ Child births per 1,000 women } \\
\hline & \multicolumn{2}{|c|}{ Households w/o children } & \multicolumn{2}{|c|}{ Households with children } \\
\hline & $\begin{array}{c}\text { High share soc. } \\
\text { dem }\end{array}$ & $\begin{array}{l}\text { Low share } \\
\text { soc. dem }\end{array}$ & $\begin{array}{l}\text { High share } \\
\text { soc. Dem }\end{array}$ & $\begin{array}{c}\text { Low share soc. } \\
\text { dem }\end{array}$ \\
\hline$\Delta \mathrm{MC} \_1997$ & -0.0935 & 0.0628 & 0.0356 & -0.00564 \\
\hline & $(0.0874)$ & $(0.0742)$ & $(0.0648)$ & $(0.0427)$ \\
\hline$\Delta \mathrm{MC} \_1998$ & $-0.288 * * *$ & 0.00263 & 0.0419 & 0.0101 \\
\hline & $(0.102)$ & $(0.0884)$ & $(0.0548)$ & $(0.0448)$ \\
\hline$\Delta \mathrm{MC} 1999$ & -0.0270 & -0.123 & -0.0606 & $-0.0909 *$ \\
\hline & $(0.103)$ & $(0.0809)$ & $(0.0712)$ & $(0.0485)$ \\
\hline$\Delta \mathrm{MC} \_2000$ & $-0.194 *$ & -0.0779 & 0.0651 & 0.0451 \\
\hline & $(0.107)$ & $(0.0803)$ & $(0.0641)$ & $(0.0348)$ \\
\hline$\Delta \mathrm{MC} 2001$ & -0.0457 & -0.0276 & -0.0137 & -0.00246 \\
\hline & $(0.134)$ & $(0.0658)$ & $(0.0684)$ & $(0.0279)$ \\
\hline$\Delta \mathrm{MC} 2002$ & -0.0170 & -0.0452 & -0.0933 & -0.0236 \\
\hline & $(0.0958)$ & $(0.0793)$ & $(0.0637)$ & $(0.0305)$ \\
\hline$\Delta \mathrm{MC} 22003$ & -0.0461 & -0.0540 & 0.0654 & -0.0125 \\
\hline & $(0.0873)$ & $(0.0960)$ & $(0.0767)$ & $(0.0370)$ \\
\hline$\Delta S Q \_1997$ & & & -0.0239 & 0.00708 \\
\hline & & & $(0.101)$ & $(0.0493)$ \\
\hline$\triangle S Q \_1998$ & & & 0.0209 & 0.0766 \\
\hline & & & $(0.0956)$ & $(0.0627)$ \\
\hline$\Delta S Q \_1999$ & & & 0.0499 & 0.000261 \\
\hline & & & $(0.122)$ & $(0.0376)$ \\
\hline$\Delta \mathrm{SQ} \_2000$ & & & -0.0441 & 0.00851 \\
\hline & & & $(0.104)$ & $(0.0461)$ \\
\hline$\Delta \mathrm{SQ} 2001$ & & & 0.0757 & -0.0433 \\
\hline & & & $(0.116)$ & $(0.0454)$ \\
\hline$\Delta S Q \_2002$ & & & 0.149 & -0.00464 \\
\hline & & & $(0.122)$ & $(0.0550)$ \\
\hline$\Delta S Q \_2003$ & & & 0.0469 & 0.00512 \\
\hline & & & $(0.0857)$ & $(0.0486)$ \\
\hline Control variables & Yes & Yes & Yes & Yes \\
\hline Year FE & Yes & Yes & Yes & Yes \\
\hline $\begin{array}{l}\text { Household } \\
\text { typexyear FE }\end{array}$ & No & No & Yes & Yes \\
\hline F-test $\Delta \mathrm{MC} \_1998-$ & 14.54 & 7.87 & 0.00 & 2.30 \\
\hline$\Delta \mathrm{MC}_{-} 2003^{-}$ & $(0.0002)$ & $(0.0059)$ & $(0.9700)$ & $(0.1320)$ \\
\hline (p-value) & & & & \\
\hline F-test $\triangle \mathrm{SQ} 1998-$ & & & 2.06 & 0.41 \\
\hline $\begin{array}{l}\Delta S Q \_2003 \\
\text { (p-value) }\end{array}$ & & & $(0.1543)$ & $(0.5243)$ \\
\hline Observations & 19,052 & 25,541 & 254,382 & 370,275 \\
\hline R-squared & 0.130 & 0.112 & 0.086 & 0.098 \\
\hline
\end{tabular}

Note: Robust standard errors clustered at the municipal level in parenthesis. ${ }^{*}$ indicates significance at the $10 \%$ level, $* *$ at the $5 \%$ level and $* * *$ at the $1 \%$ level. Household types are defined by the number of children under 
the age of 10, the exact age of the youngest child, the age category (ages $0-3,4-5,6-9$ ) of the next three youngest children and a household monthly income span of 1,000 SEK. Control variables are woman's age and education, and local unemployment.

\section{Conclusions}

We have studied the effect of reducing childcare costs on the fertility behavior of Swedish families. We explore the variation in costs induced by a childcare fee reform which was announced as an election promise of the Social Democrats in 1998 and was implemented in 2002. The reform lowered the marginal cost of having additional children, but also implied a positive income shock for families that already had children enrolled in childcare.

Our analysis of the dynamics of childbirth for the years around the reform suggests that married couples without children reacted already to the election victory of the Social Democrats in 1998 by having children. It was primarily low income households which increased fertility. The somewhat surprising early reaction suggests that the election promise was regarded as credible. It is plausible that the election promise seem more credible for households in municipalities dominated by Social Democrats. In line with this reasoning we find that only married couples in those municipalities reacted to the election promise. The reform implied a total reduction of child care costs of on average 111000 SEK (17 000 USD), which is about a quarter of a years' earnings for these households. The effect was to increase fertility by 9.8 per cent.

Households with one child did not increase their total demand for children, but appear to have postponed second births. One explanation for this could be that these household timed the second child to make sure they benefitted from the low cost for a maximal time. There is some evidence that families with two or more children increased fertility as a response to the reduction in the marginal cost. The reform induced a marginal child care cost reduction of 18 percent of a year's family earnings and the estimated effect implies an increase in higher order births with some 14.5 percent. The total effect is however only marginally significant. Moreover, because the present reform also implied that families with children already enrolled in childcare experienced a positive income shock, which appears to have had a negative effect on the demand for children, it is not clear what the overall impact of the reform was. Effects may well cancel out. 
We can compare the magnitude of the estimated effect with the findings of other studies that investigate the effect of other economic incentives on fertility. Milligan (2005) investigates the effects of a pro-natalist transfer policy implemented in Quebec, in which mothers received a cash bonus for giving birth. Using the exogenous variation created by the reform, he finds that there is a substantial impact of childcare allowances on fertility rates. Milligan finds that a cash bonus of 1,000 Canadian Dollars (USD 950) increased fertility by 16 percent. Laroque and Salanié (2004), instead, apply a structural model of maternal labor supply and fertility to French data and family policies (although ignoring the effects of childcare). In simulations, they find that increasing mothers' earnings reduces fertility but that increasing child support during the first three years, with what would correspond to a present value cash transfer of some USD 20,000, would increase fertility by a quarter. Finally, Cohen et al (2009) find, investigating the effects of Israeli child subsidies, that a reduction of USD 34 in monthly subsidies for a marginal child decreases fertility by 8 percent. As in this study Cohen et al (2009) find a negative income effect for some households. The price effects found in this study for childless households are in comparison to the studies mentioned above somewhat smaller in magnitude.

It is difficult to assess if the effect on first births has any long run impact on cohort fertility. The timing effect on families with one child, suggests that the reform did not increase the demand for a second child. The reform effects on higher order births, however, suggest that reduced marginal costs may have influenced total fertility, although this effect is largely cancelled out by a negative income effect of the lower childcare costs for the children already enrolled in childcare. 


\section{References}

Adsera A (2004) Changing fertility rates in developed countries. The impact of labor market institutions. J of Popul Econ 17:17-43

Adsera A (2005) Vanishing children: From high unemployment to low fertility in developed countries. Am Econ Rev Pap and Proc 95:189-193

Angrist J, Lavy V, Schlosser A (2010) Multiple experiments for the causal link between the quantity and quality of children. J of Lab Ec 28:773-824

Apps P, Rees R (2004) Fertility, female labor supply and public policy. Scand J of Econ 106:745-763

Björklund A (2006) Does family policy affect fertility?. J of Popul Econ 19:3-24

Blau DM, Robins P K (1989) Fertility, employment, and child-care costs. Demogr 26:287-299

Cohen A, Dehejia R, Romanov D (2009) Do financial incentives affect fertility? NBER Working Paper 13700.

Cortes P, Tessada J (2009) Low-skilled immigration and the labor supply of highly educated women. Manuscript, University of Chicago.

D'Addio AC, d'Ercole, M (2005) Trends and determinants of fertility rates in OECD countries: The role of policies. OECD Social, Employment and Migration Working Paper No 27

Del Boca D (2002) The Effect of Child Care and Part Time Opportunities on Participation and Fertility Decisions in Italy. J of Popul Econ 15:549-573

Elinder M, Jordahl H, Poutvara P (2008) Selfish and prospective: Theory and evidence of pocketbook voting. CESifo Working paper No 2489

Ermisch JF (1989a) Fertility employment and child-care costs. Demogr 26:287-299

Ermisch JF (1989b) Purchased child care, optimal family size and mother's employment. J of Popul Econ 2:79-102

Furtado D, Hock H (2010) Immigrant labor, child-care services, and the work-fertility trade-off in the United States. Am Econ Rev Pap and Proc 100:224-228

Kearney M (2004) Is there an effect of incremental welfare benefits on fertility behavior? A look at the family cap. J of Hum Resour 392:295-325 
Laroque G, Salanié B (2004). Fertility and financial incentives in France. CESifo Econ Stud 50:423-450.

Lundin D, Mörk E, Öckert B (2008). How far can reduced childcare prices push female labour supply?. Lab Econ 15:647-659

Milligan K (2005) Subsidizing the stork: New evidence on tax incentives and fertility. Rev of Econ and Stat 87:539-555

Moffit R (2005) Remarks on the analysis of causal relationships in population research. Demogr 42:91-108

OECD (2005) Babies and bosses: Reconciling work and family life? Canada, Finland, Sweden and the United Kingdom.

Schlosser A (2006) Public preschool and the labor supply of Arab mothers: Evidence from a natural experiment. Mimeo Hebrew University, Jerusalem.

Skolverket (1999). Avgifter i förskola och fritidshem 1999. Rapport 174

Skolverket (2003) Avgifter i förskola och fritidshem. Fördjupning av rapport 231

Skolverket (2007) Barns omsorg. Tillgång och efterfrågan på barnomsorg för barn 1-12 år med olika social bakgrund. Rapport 203

Smith J, Todd P (2005) Does matching overcome LaLonde's critique of nonexperimental estimators?. J of Econometrics 125:305-335 


\section{Appendix}

Table A.1 Variable definitions

Child: Dummy that takes the value 1 if the household had a child in an 12-month period

Marginal cost: The present value of the cost of an additional child enrolled in full-time child care until the age of 9 .

Status quo childcare cost: The present value of the child care costs associated with having the family's existing children enrolled in full-time childcare until the age of 9.

Age: Age of the women in the households minus the median age (34)

University: Dummy that takes the value 1 if the woman in the household has some university education

The data is collapsed at the household-municipal level, and therefore one observation will be the household type $\times$ municipality averagexyear

Unemployment: Unemployment rate at municipality level 
Table A.2 Birth rates per 1000 women 1997-2001 and mean characteristics in 2000

\begin{tabular}{|c|c|c|c|c|}
\hline \multirow[b]{2}{*}{ Variable } & \multirow{2}{*}{$\begin{array}{l}\text { Childless } \\
\text { households }\end{array}$} & \multicolumn{3}{|c|}{ Households with children } \\
\hline & & All & one child & $\begin{array}{l}\text { at least } \\
\text { two } \\
\text { children }\end{array}$ \\
\hline $\begin{array}{l}\text { Births per } 1000 \text { 1997: } \\
\text { July1998-June } 1999\end{array}$ & $\begin{array}{l}142.66 \\
(138.49)\end{array}$ & $\begin{array}{c}74.37 \\
(163.97)\end{array}$ & $\begin{array}{l}118.98 \\
(198.17)\end{array}$ & $\begin{array}{c}34.31 \\
(111.23)\end{array}$ \\
\hline $\begin{array}{l}\text { Births per } 10001998: \\
\text { July1999-June } 2000\end{array}$ & $\begin{array}{c}146.64 \\
(155.10)\end{array}$ & $\begin{array}{c}71.83 \\
(169.56)\end{array}$ & $\begin{array}{c}114.38 \\
(204.24)\end{array}$ & $\begin{array}{c}34.59 \\
(120.12)\end{array}$ \\
\hline $\begin{array}{l}\text { Births per } 1000 \text { 1999: } \\
\text { July2000-June } 2001\end{array}$ & $\begin{array}{c}154.12 \\
(162.12)\end{array}$ & $\begin{array}{c}71.75 \\
(173.15)\end{array}$ & $\begin{array}{c}113.02 \\
(206.25)\end{array}$ & $\begin{array}{c}35.18 \\
(126.53)\end{array}$ \\
\hline $\begin{array}{l}\text { Births per } 1000 \text { 2000: } \\
\text { July2001-June } 2002\end{array}$ & $\begin{array}{c}164.62 \\
(171.25)\end{array}$ & $\begin{array}{c}73.68 \\
(177.20)\end{array}$ & $\begin{array}{c}114.46 \\
(208.90)\end{array}$ & $\begin{array}{c}35.95 \\
(130.83)\end{array}$ \\
\hline $\begin{array}{l}\text { Births per } 1000 \text { 2001: } \\
\text { July2002-June } 2003\end{array}$ & $\begin{array}{c}172.82 \\
(176.63)\end{array}$ & $\begin{array}{c}78.39 \\
(183.53)\end{array}$ & $\begin{array}{c}119.18 \\
(213.90)\end{array}$ & $\begin{array}{c}38.84 \\
(137.13)\end{array}$ \\
\hline$\Delta \mathrm{MC}$ year 2000, SEK 1000 & $\begin{array}{l}111.49 \\
(42.66)\end{array}$ & $\begin{array}{c}77.18 \\
(47.87)\end{array}$ & $\begin{array}{c}83.68 \\
(49.79)\end{array}$ & $\begin{array}{c}71.18 \\
(45.20)\end{array}$ \\
\hline$\Delta$ SQ year 2000, SEK 1000 & & $\begin{array}{c}62.17 \\
(50.60)\end{array}$ & $\begin{array}{c}48.88 \\
(48.01)\end{array}$ & $\begin{array}{c}74.45 \\
(49.82)\end{array}$ \\
\hline Age of woman year 2000 & $\begin{array}{l}33.88 \\
(3.79)\end{array}$ & $\begin{array}{l}34.70 \\
(4.33)\end{array}$ & $\begin{array}{l}35.33 \\
(4.95)\end{array}$ & $\begin{array}{l}34.11 \\
(3.56)\end{array}$ \\
\hline University educated year 2000 & $\begin{array}{c}0.37 \\
(0.26)\end{array}$ & $\begin{array}{c}0.29 \\
(0.31)\end{array}$ & $\begin{array}{c}0.29 \\
(0.29)\end{array}$ & $\begin{array}{c}0.29 \\
(0.33)\end{array}$ \\
\hline $\begin{array}{l}\text { Monthly household income year } \\
2000 \text { SEK }\end{array}$ & $\begin{array}{c}369,54 \\
(178,40)\end{array}$ & $\begin{array}{c}33,120 \\
(13,738)\end{array}$ & $\begin{array}{c}33,235 \\
(13,819)\end{array}$ & $\begin{array}{c}33,014 \\
(13,661)\end{array}$ \\
\hline Number of household types & 8,055 & 136,468 & 55,613 & 80,855 \\
\hline Number of households & 36,732 & 323,795 & 155,580 & 168,215 \\
\hline
\end{tabular}

Note: Standard deviation in parenthesis 